\title{
درجة ممارسة إدارة التغيير وعلاقتها بمستوى الإبداع الإدارى لدى قادة مدارس المرحلة الثانوية بمحافظة المخو اة من وجهة نظر المعلمين
}

\author{
الباحث / سامي أحمد سعد الزبيدي
}

إشراف ا.د شريف محمد شريف

أستاذ الإدارة و التخطيط التربوي بقسم الإدارة و التخطيط التربوي

\section{بكلية التربية جامعة الباحة}

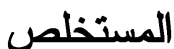

هدفت الدر اسة إلى التعرف على درجة ممارسة إدارة التغيير وعلاقتها بمستوى الإبداع الــإدارى لـدى قـادة مدارس المرحلة الثانوية بمحافظة المخو اة من وجهة نظر المعلمين. و قد استخدم الباحث المنهج الوصفي الارتبـاطى،

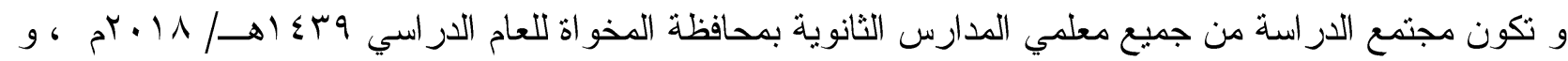

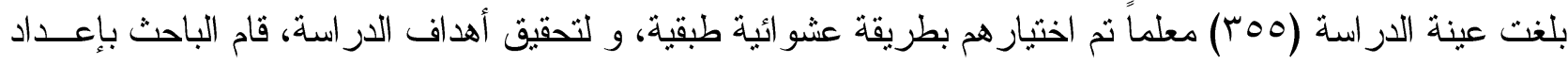

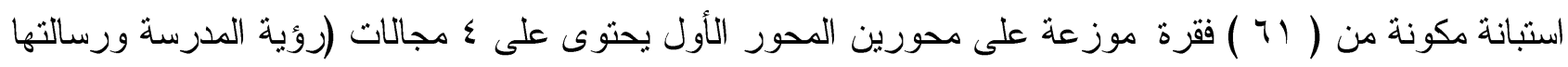

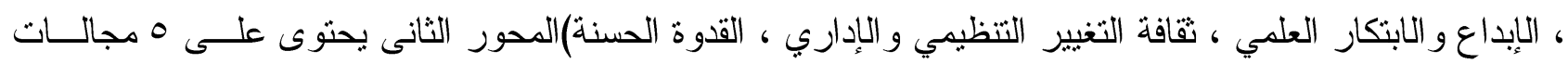

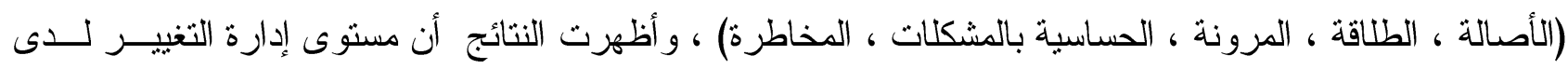

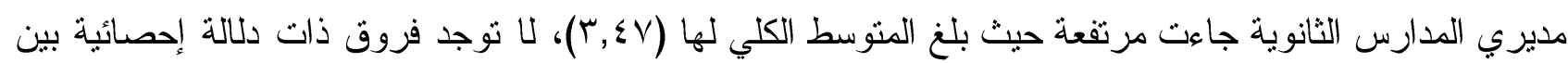

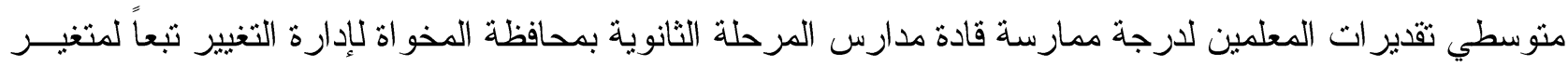

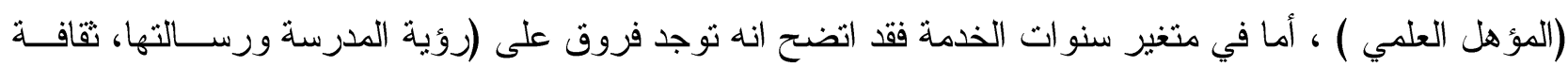

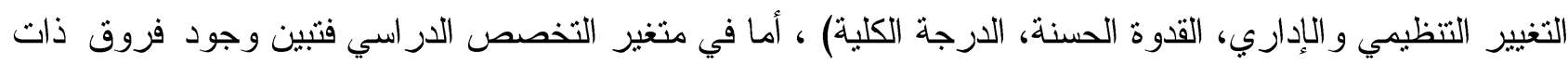

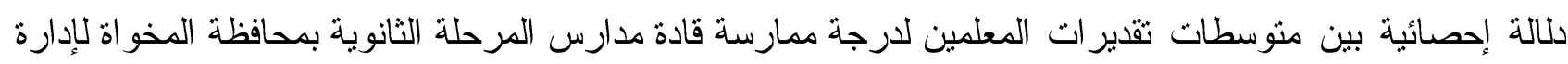

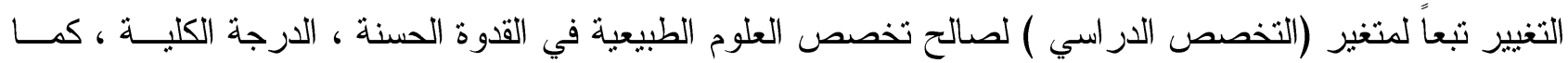

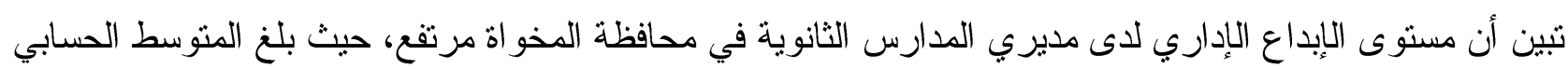

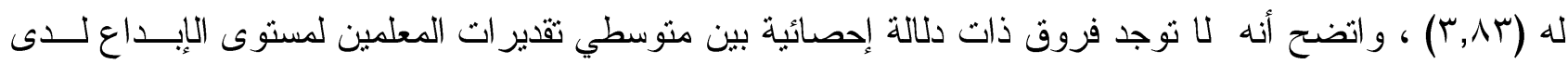

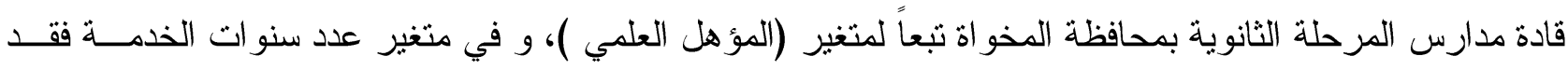

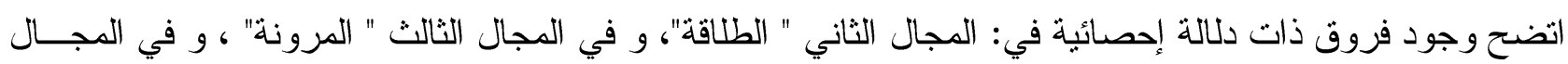

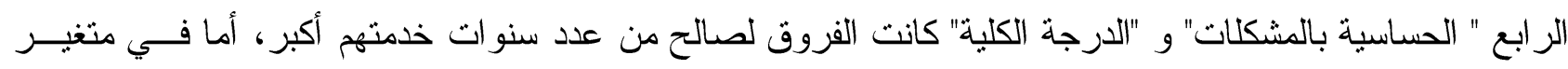

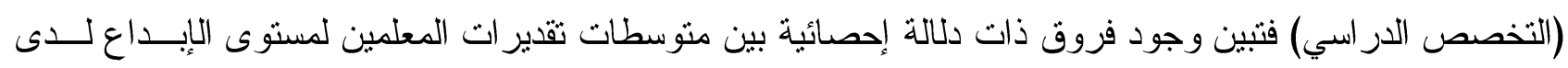

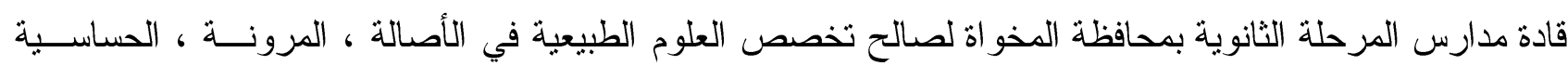

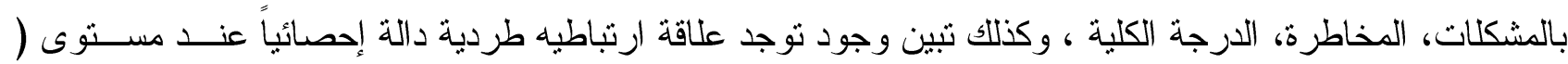

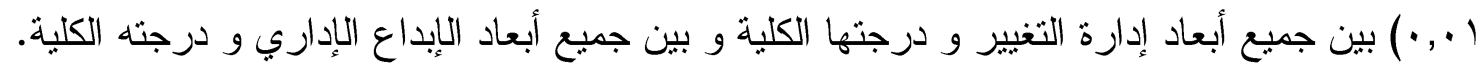




\begin{abstract}
The study aimed to identify the degree of change management practice and its relation to the level of administrative creativity among the leaders of the secondary schools in Al-Makhwa Governorate from the point of view of the teachers. The researcher used the descriptive the associative approach, the study community shall be from all the secondary school teachers in AlMakhwah governorate for the academic year $1439 \mathrm{H} / 2018$, the sample of the study (355) teachers were selected in a random manner, to achieve the objectives of the study, the researcher prepared a questionnaire consisting of (61) sections divided into two axes. The first axis contains four areas (school vision and mission, creativity and scientific innovation, organizational and administrative change culture, good example) the second axis contains 5 areas (originality, fluency, flexibility, sensitivity to problems, risk), the results showed that the level of change management among high school principals was high, with a total average of (3.47), there were no statistically significant differences between the average teachers' estimates of the degree of leadership of secondary school students in Al-Makhwah governorate to manage the change according to the variable (qualification), in the variable years of service, it was found that there were differences on (school vision and mission, culture of organizational and administrative change, good example, total degree), as for the variable of study specialization, there were statistically significant differences between the average of teachers' estimations and the level of practice of secondary school leaders makhawh governorate to manage change according to the variable (specialization) for the benefit of natural sciences in good example, overall, the level of administrative innovation among secondary school principals in Al-Mahwah Governorate was high, with an average of $(3,83)$, it was found that there are no statistically significant differences between the average teachers' assessment of the level of innovation among the leaders of the secondary schools in Al-Makhwa governorate according to the variable (the qualification), and in the variable number of years of service it was found that there are differences of statistical significance in: the second area "fluency", and in the third area "flexibility", and in the fourth area "sensitivity to problems" and "total score" were the differences in favor of the number of years of service is greater, In the variable (study specialization), there are statistically significant differences between the average teachers' assessment of the level of creativity among the leaders of the secondary schools in Al-Makhwa governorate in favor of the natural sciences specialization in originality, Flexibility, sensitivity to problems, risk, total score, it was also found that there is a positive correlation relationship statistically significant at $(0.01)$ between all dimensions of change management and its overall degree and between all dimensions of administrative innovation and its overall degree.
\end{abstract}




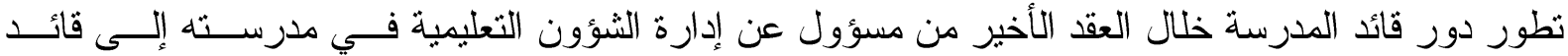

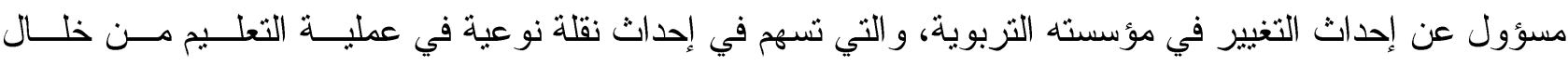
التعامل مع أفر اد المدرسة بكل بسر وسهولة، و اتخاذ القز ار ات السليمة وتوفير جو مدرسي مناسب بسهم فــي الرقـي

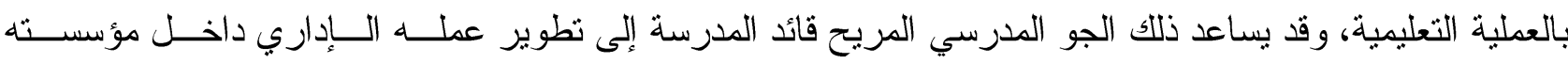
التربوية، مما قد تزفع من مستوى الإبداع لديه.

و إذا أر اد قائد المدرسة من تحقيق الأهداف التزبوية و التعليمية وتحقيق مستوى الإبداع الإداري في عمله، فلابـــ

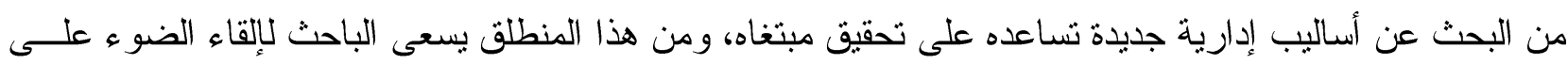

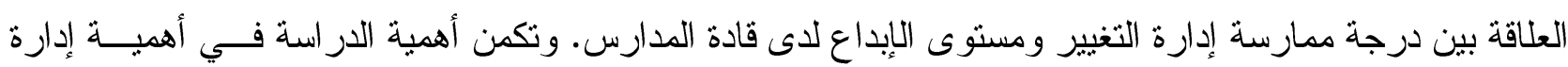
التغير و الإبداع لدى قائد المدرسة، حيث أن كل منهما يساهم بدرجة كبيرة في مو اكبة منطلبات العصر ، ونو افر قائــــ

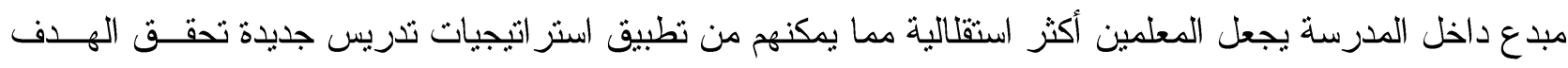
المنشود، بالإضافة إلى أنه يفتح الباب أمام الطلاب للتعبير عن آر ائهم ومقترحاتهم مما يجعلهم أكثر انجذاباً للمدرسة. ومن خلال استعر اض الباحث للدر اسات السابقة ، ومن منطلق توجهات المملكة العربية السعودية لتطوير التعليم حسب رؤية • ـ • ب لمو اكبة التطور ات في هذا العصر ، الأمر الذي دعا الباحث إلى در اسة العلاقة بين درجة ممارسة إدارة التغيير ومستوى الإبداع لاى قادة المدارس الثانوية بمحافظة المخو اة في المملكة العربية السعودية.

مشكلة الدر اسة و أسئلتها:

يلاحظ الباحث من خلال عمله الحالي كقائد مدرسة أن نظام التعليم في المملكة العربية السعودية شهر عديد مسن

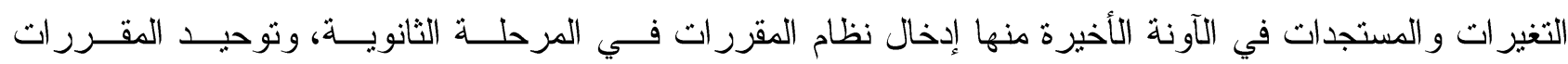
و تطوير ها، و إلغاء الاختبار ات في بعض المر احل و استبدالها بالثقويم المستمر ، و إلغاء مركزية اختبار ات الثانوية العامة

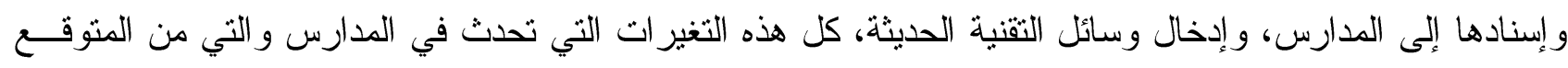
زيادتها في المستقبل، غالباً ما تؤثر على نوازنها، ولذا تتطلب أسلوباً إدارياً بختلف عن الأسلوب التقليدي لمسايرة هذه

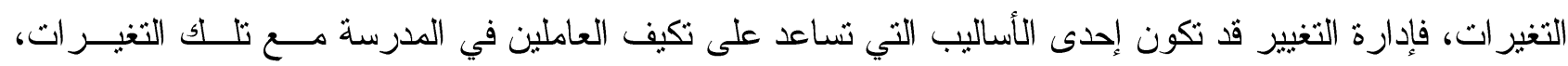
وتوفير جو مدرسي ملائم لأفر اد المدرسة. ومن هذا المنطلق سوف يحاول الباحث في هذه الدر اسة معرفة درجة ممارسة إدارة التغيير وعلاقتها بمسـتوى ملتى الإبداع لاى قادة مدارس المرحلة الثانوية بمحافظة المخو اة في المملكة العربية السعودية من وجهة نظر المعلمين. أسئلة الدر اسةة: تتحدد مشكلة الدر اسة في الإجابة عن التساؤل الرئيس التالي: ما العلاقة بين درجة ممارسة إدارة التغيير ومستوى الإبداع لــدى قــادة مــدارس المرحلـــة الثانويـــة بمحافظـــة المخواة من وجهة نظر المعلمين؟ ويتفرع من هذا السؤ ال التساؤلات الفرعية التالية: 
ا ـ ما درجة ممارسة إدارة التغيير لدى قادة مدارس المرحلة الثانوية بمحافظة المخو اة من وجهة نظر المعلمين؟

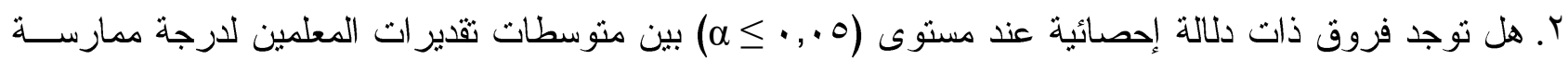
قادة مدارس المرحلة الثانوية بمحافظة المخواة لإدارة التغيير تبعاً لمتغيرات الدراسة (المؤهل العلمــي، ســنوات

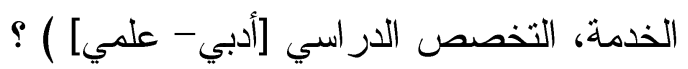

ץ. ما مستوى الإبداع لاى قادة مدارس المرحلة الثانوية بمحافظة المخو اة من وجهة نظر المعلمين؟

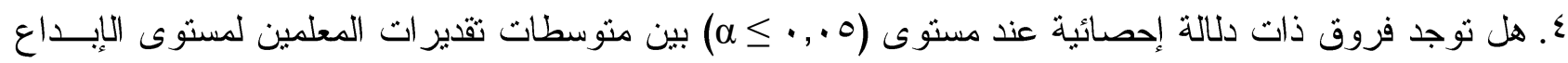
لاى قادة مدارس المرحلة الثانوية بمحافظة المخواة تبعاً لمتغيرات الدراسة (المؤهل العلمــي، ســنوات الخدمــة،

$$
\text { التخصص الدر اسي [أدبي- علمي] )؟ }
$$

๑. هل توجد علاقة ارتباطية ذات دلالة إحصائية بين درجة ممارسة إدارة التغيير ومستوى الإبداع لدى قادة مــدارس

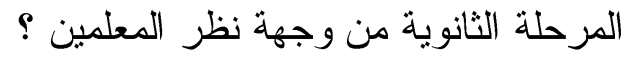

أهداف الدر اسة:

تتلخص أهداف هذه الدراسة في معرفة العلاقة بين درجة ممارسة إدارة التغيير ومستوى الإبداع لدى قادة مدارس المرحلة الثانوية بمحافظة المخو اة من وجهة نظر المعلمين. ثانياً: الدر اسات السابقة سوف يتتاول الباحث الدراسات السابقة الني تتاولت منغيري إدارة التغيير و الإبداع ، ومن ثم التعقيب على هذه الدر اسات، و أوجه الاستفادة منها، وسوف تقسم الدر اسات إلى محورين هما: المحور الأول: دراسات تتاولت إدارة التغيير وعلاقتها بيعض المتغيرات

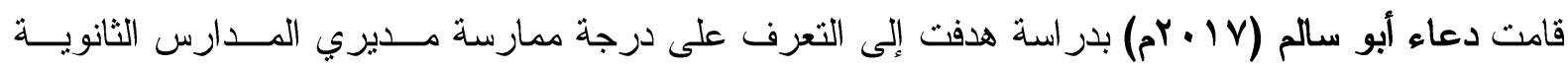

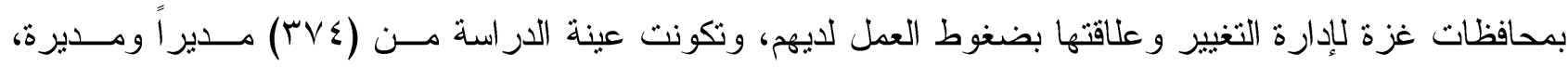
و استخدمت الباحثة المنهج الوصفي التحليلي، واستخدمت الباحثة الاستبانة لجمع المعلومات من إعـدادها، وتوصــلت الدر اسة إلى نتائج من أبرزها أن درجة ممارسة مديري المدارس الثانوية لإدارة التغيير جاءت بدرجة كبيرة، ووجــود فروق ذات دلالة إحصائية لارجة ممارسة مديري المدارس الثانوية لإدارة التغيير تعـزى لمتغيــر الجــس، لصــالح الذكور، و إلى متغير سنوات الخدمة لصالح الذين سنوات خدمتهم عشر سنوات فأكثر، ووجود علاقة ارتباطية ســالبة ذات دلالة إحصائية بين درجة ممارسة مديري المدارس الثانوية لإدارة التغيير وبين مستوى ضغوط العمل لديهم. بينما أجرى المطيري (1 ( • Yم) در اسة هدفت إلى التعرف على درجة ممارسة مــديري المــدارس الثانويــة

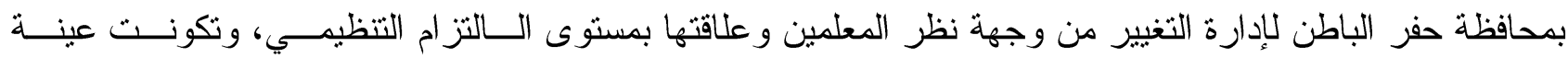

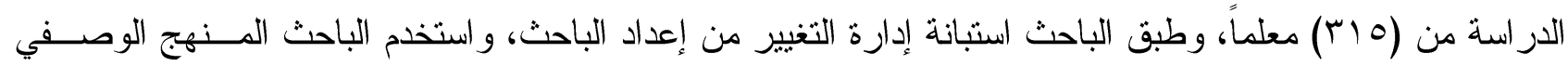
التحليلي، وتوصلت الدراسة إلى نتائج أبرزها أن درجة ممارسة مديري المدارس الثانوية جاءت بدرجة غالباً، ووجود علاقة طردية إيجابية بين و اقع إدارة التغيير لاى مديري المدارس الثانوية ومسنوى الالتز ام التنظيمي للمعلمين، وعــدم وجود فروق ذات دلالة إحصائية في درجة ممارسة مديري المدارس الثانوية لإدارة التغيير من وجهة نظر المعلمــين تعزى لسنو ات الخدمة، ووجود فروق ذات دلالة إحصائية وفق متغير ات: المؤهل العلمي، ونوع المؤهل. أما أبو حسنين (10 • rم) بدر اسة هدفت إلى التعرف على درجة ممارسة المشرفين التربويين لإدارة التغيير و علاقتها بمستوى أداء معلميهم في مدارس وكالة الغوث بمحافظات غزة، وتكونت عينة الدراسة من (YNM) معلماً 
ومعلمة، واستخدم الباحث استبانة إدارة التغييز من إعداده، واتبع الباحث المنهج الوصفي التحليلي، وبينت النتائج أن درجة ممارسة المشرفين التزبوبين لإدارة التغيير جاءت بدرجة جيدة، وعدم وجود فروق ذات دلالة إحصائية في استجابات أفر اد العينة لدرجة ممارسة المشرفين التربويين لإدارة التغيير تعزى لمتغيرات سنوات الخدمة و المؤهل العلمي، ووجود علاقة ارتباطية موجبة دالة احصائياً بين درجة ممارسة المشرفين التزبويين لإدارة التغيير و أداء المعلمين من وجهة نظر المعلمين. المحور الثاني: در اسات ثتاولت متغير الإيداع و علاقته بيعض المتغيرات

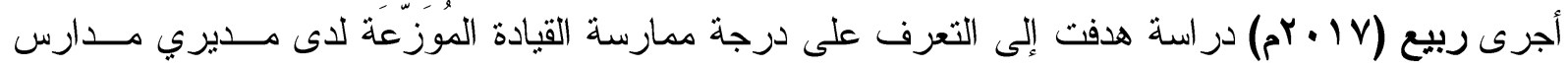

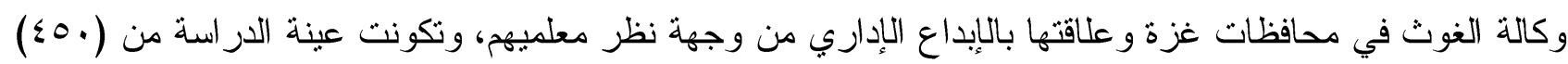

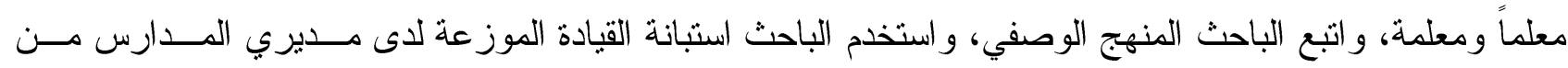
إعداد الباحث، و استبانة الإبداع الإداري لإى مديري المدارس من وجهة نظر معلميهم من إعداد الباحسث، وتوصــلت الدر اسة إلى نتائج أبرزها أن درجة ممارسة مديري المدارس للإبداع الإداري من وجهة نظر معلميهم جاءت بدرجـة كبيرة، ووجود علاقة موجبة ذات دلالة إحصائية بين درجة تقدير أفر اد العينة لممارسة القيادة الموزعة لــدئ مــديري المدارس الثانوية ودرجة تقدير هم للإبداع الإداري. أما الشاعر (1 1 +rم) قام بدر اسة هدفت إلى التعرف على درجة ممارسة الإبداع الإداري وعلاقته بالمهــار ات القيادية لاى مديري مدارس وكالة الغوث الدولية بمحافظات غزة من وجهة نظر المعلمين، وتكونت عينة الدراسة من ( . . (0) معلماً ومعلمة، و اتبع الباحث المنهج الوصفي، و استخدم الباحث استبانتين كأداة لجمع المعلومات من إعــداده، وتوصلت الدر اسة إلى نتائج كان من أبرزها أن درجة ممارسة مديرو المدارس للإبداع الإداري جاءت بدرجة مرتفعة،

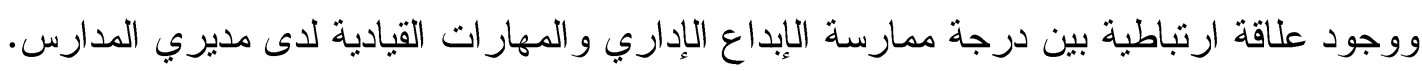
وكذلك قامت غادة خطاطبة (7 ( • rم) بدر اسة هدفت إلى التعرف على درجة ممارسة مديري المدارس الثانوية

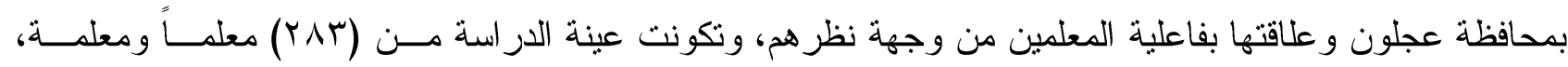
و استخدم الباحث المنهج الوصفي، كما استخدم الباحث الاستبانة لجمع المعلومات من تطويره، وتوصلت الدراسة إلـى

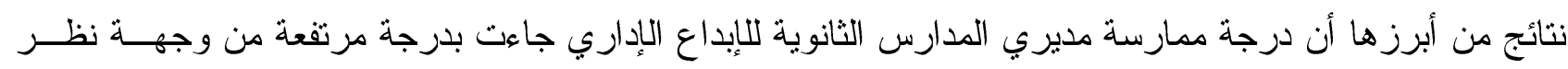

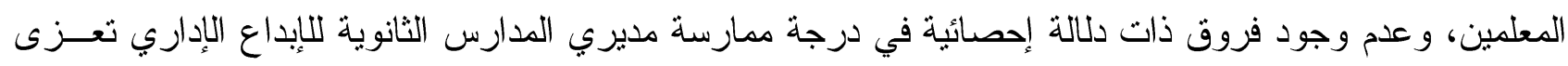
لمتغير الجنس، ووجود فروق ذات للالة إحصائية في درجة ممارسة مديري المدارس الثانوية للإبداع الإداري تعـزى لمتغيري المؤهل العلمي، وسنو ات الخبرة ولصالح من لديه خبرة عشر سنوات فأقل. وقام مديس (ع ا +rم) بدر اسة هدفت إلى الكثف عن درجة ممارسة الإبداع الإداري لإى القادة التزبويين فـي منطقة الباحة التعليمية من وجهة نظر المشرفين التزبويين، وتكونت عينة الدر اسة مـن (rع () مشــرفاً، و اســتخدم الباحث المنهج الوصفي المسحي، واستخدم الباحث الاسنبانة لجمع المعلومات من إعداده، وتوصلت الدر اسة إلى نتائج

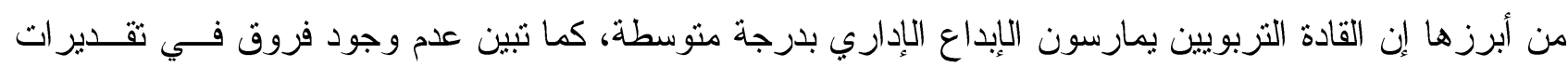

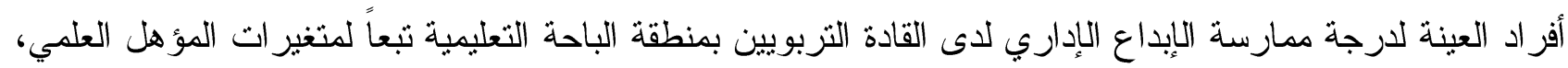
وسنوات الخدمة، و المجال الإثر افي. 
عرض الباحث في هذا الفصل الخطوات و الإجراءات التي قام بها لتحقيق أهداف الدراسة من حيث منهج الدراسة، و المجتمع، و العينة، ومتغيرات الدراسة، و الأدوات المستخدمة، و إجراءات تطبيق الدراسة، و والأساليب الإحصائية المتبعة كما يلي:

منهج الدراسة:

استخدم الباحث المنهج الوصفي (الارتباطي) لملاءمته لموضوع و أهداف الدراسة، حيث يقوم هذا المنهج بدر اسة الظاهرة كما توجد في الو اقع بوصفها وصفاً دقيقاً، عن طريق جمع المعلومات وتتظيمها و التعبير عنها كماً

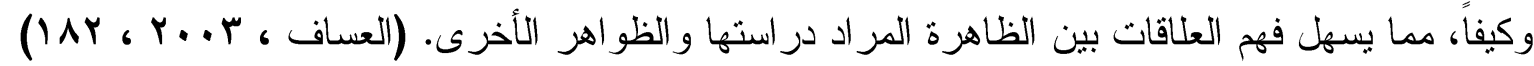
مجتمع الدراسة: يتكون مجتمع الدر اسة من جميع معلمي مدارس المرحلة الثانوية بمحافظة المخواة في المملكة العربية السعودية

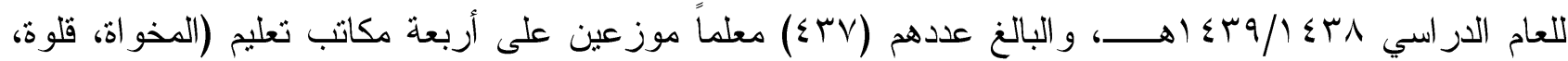
الحجرة، الفرعة). عينة الدر اسة:

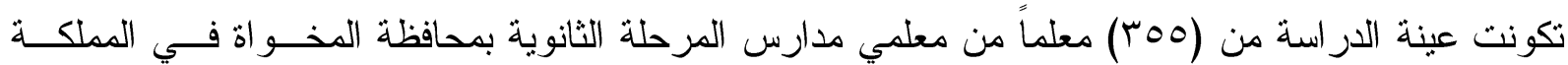
العربية السعودية، وتم اختيار هم بطريقة العينة الطبقية العشو ائية ، حيث قام الباحث بتقسيم المجتمع إلى طبقات، ومــن ثم إيجاد حجم العينة من كل طبقة عن طريق المعادلة الثالية: حجم العينة الطبقية = (حجم الطبقة بـ حجم المجتمـعـ) × حجم العينة، ثم قام بإعداد قائمة بالمدارس في كل طبقة (مكتب الإثر اف)، وتم سحب أسماء المدارس من كــل قائمـــة بالطريقة العشو ائية، وقام الباحث بتوزيع أدوات در استه على جميع المعلمين و المعلمــات فــي المــدارس المختــارة عشو ائياً. خصائص عينة الدراسة: فيما يلي وصف عينة الدر اسة حسب المتغير ات الديمو غر افية: ا ـ متغير المؤهل العلمي:

جدول (r)

توزيع أفراد عينة الدراسة وفقاً لمتغير المؤهل العلمي

\begin{tabular}{|c|c|c|c|}
\hline النسبة \% & التكرار & المؤهل العلمي & b \\
\hline 97.7 & 347 & بكالوريوس & 1 \\
\hline 2.3 & 8 & در اسات عليا & r \\
\hline$\% 1 \ldots$ & 355 & \multicolumn{2}{|c|}{ المجموع } \\
\hline
\end{tabular}

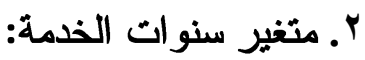

جدول (乏)

توزيع أفر اد عينة الدراسة وفقاً لمتغير سنوات الخدمة

\begin{tabular}{|c|c|c|c|}
\hline النسبة \% & التكر ار & سنوات الخدمة & r \\
\hline 18.6 & 66 & أقل من ه سنو ات & 1 \\
\hline 52.1 & 185 & من 0 - . 1 سنوات & r \\
\hline 29.3 & 104 & أكثر من . سنوات & r \\
\hline
\end{tabular}

- $\varepsilon$ - 


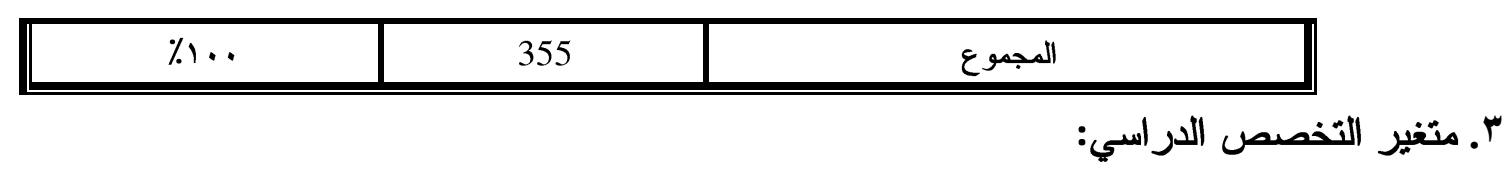

جدول (0)

توزيع أفراد عينة الدراسة وفقاً لمتغير التخصص الدراسي

\begin{tabular}{|c|c|c|c|}
\hline النسبة \% & التكرار & التخصص الدراسي & b \\
\hline 56.3 & 200 & علوم شر عية & 1 \\
\hline 43.7 & 155 & علوم طبيعية & r \\
\hline$\% 1 \ldots$ & 355 & لمجموع & \\
\hline
\end{tabular}

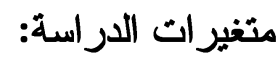
سوف تشتمل هذه الدر اسة على عدة متغير ات وهي: المتغيرات الديموغر افية: وتشمل المتغير ات التالية: المؤهل العلمي: ويشمل الفئات التالية (بكالوريوس، در اسات عليا (دبلوم عالي - ماجستير - دكتور اه).

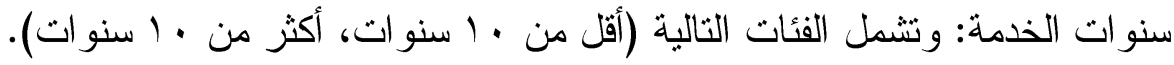
التخصص الدراسي: ويشمل الفئات التالية (أدبي- علمي). المتغير المسنقل: درجة ممارسة قادة المدارس لإدارة التغيير من وجهة نظر المعلمين. المتغير التابع: مستوى الإبداع لاى قادة المدارس من وجهة نظر المعلمين. أداة الدر اسة: استخدم الباحث الاستبانة كأداة لقياس متغير ات الدراسة و التي تنكون من جزأين هما كما يلي: الجزء الأول: يقيس درجة ممارسة إدارة التغيير من إعداد الباحث. الجزء الثاني: يقيس مستوى الإيداع من إعداد الباحث.

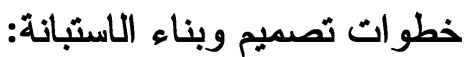
قام الباحث بإعداد استبانة تتكون من جز أين، فالجزء الأول من الاستبانة يقيس درجة ممارسة قـادة المــارس

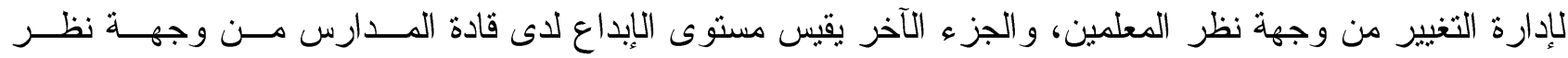
المعلمين وفق خطوات منهجية على النحو الثالي:

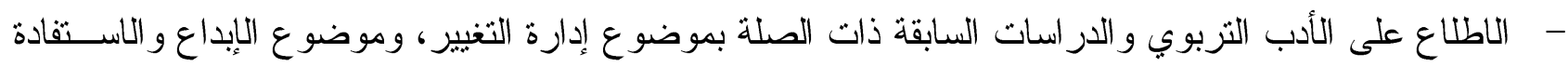
منها في بناء الاستبانة. - تحديد الأبعاد (المجالات) الرئيسية التي سوف تشتنمل عليها الاستبانة سو اء تلك التي تقيس إدارة التغيير، أو التـي تقيس مستوى الإبداع.

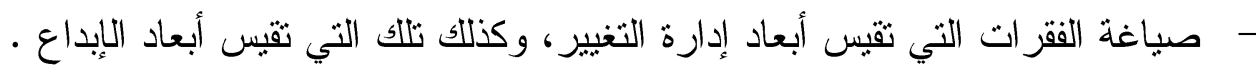

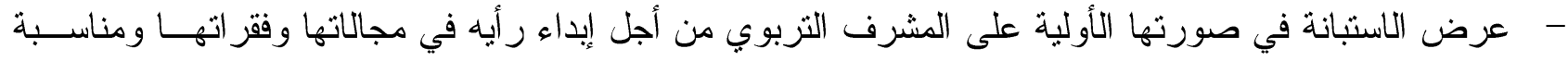
الفقر ات للججالات وصياغتها من أجل التعديل. 
- مرض عالستبانة في صورتها الأولية على (ع () من المحكمين و المختصين التزبويين لإبداء ملاحظاتهم، وتعـديل ما يستوجب تعديله على المجالات وفقر اتها.

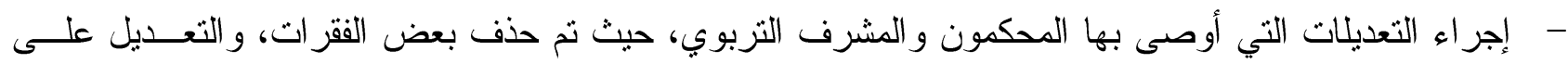

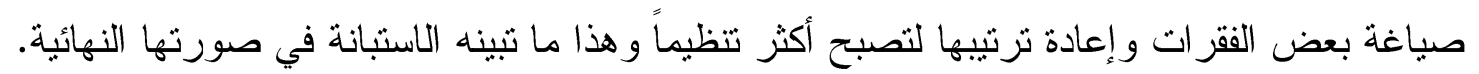
وصف أداة الدراسة: تتضمن الاستبانة (آ) فقرة موزعة على جزأين، الجزء الأول يشتمل (عَ) فقرة لقياس درجة ممارسة قادة

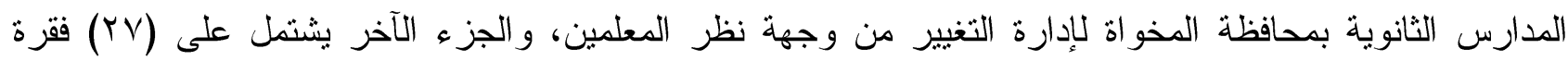

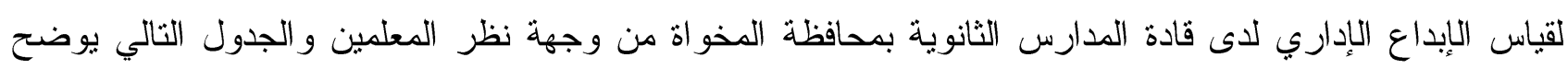
توزيع فقرات الاستبانة على المجالات في كل من الجز أين:

جدول (7) فقرات مجالات استبانة الدراسة

\begin{tabular}{|c|c|c|c|}
\hline عدد الفقرات & فقرات البعد & مجالات إدارة التغيير & 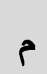 \\
\hline $\mathrm{v}$ & $\mathrm{v}$ & رؤية المدرسة ورسالتها & 1 \\
\hline 9 & 9 & الإبداع و الابتكار العلمي & r \\
\hline 9 & 9 & ثقافة التغيير التنظيمي و الإداري & $r$ \\
\hline 9 & 9 & القدوة الحسنة & $\varepsilon$ \\
\hline$r \varepsilon$ & \multicolumn{3}{|c|}{ مجموع فقزات محور إدارة التغيير } \\
\hline عدد الفقرات & فقرات البعد & مجالات الإيداع الإداري & s \\
\hline 0 & 0 & الأصالة & 1 \\
\hline 0 & 0 & 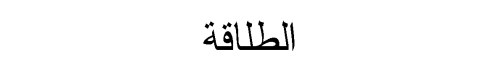 & r \\
\hline$\circ$ & 0 & المرونة & $r$ \\
\hline v & v & الحساسية بالمشكلات & $\varepsilon$ \\
\hline 0 & 0 & المخاطرة & 。 \\
\hline$r V$ & \multicolumn{3}{|c|}{ مجموع فقرات محور الإبداع الإداري } \\
\hline
\end{tabular}

طريقة تصحيح الاستبانة: تصحح البنود في المقياس الحالي في ضوء ( ( ) ) أوزان للاستجابة وهي: صغيرة جداً وقيمنها ( ()، وصــيرة

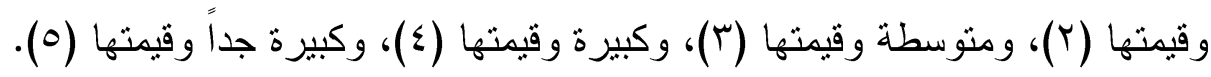
الخصائص السيكومترية للاستبانة الدراسة: قام الباحث بتطبيق الاستبانة على عينة استطلاعية تتكون من (•r) معلماً من معلمي المرحلة الثانوية بمحافظة

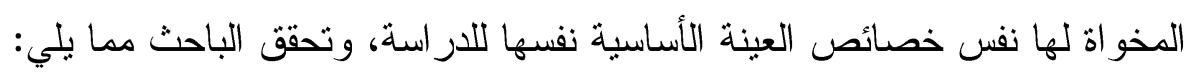

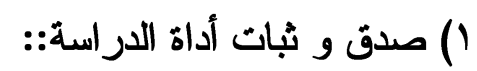
أوناً الصدق: للاتحقق من صدق الأداة تم حساب الصدق بطريقتين وهما كالتالي: 
1- (الصدق المكمين (الصدق الظاهري):

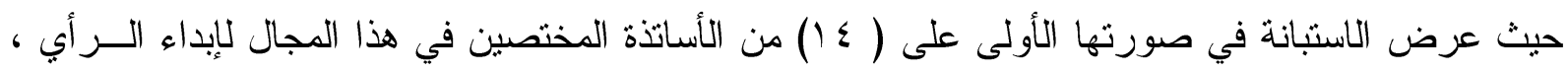

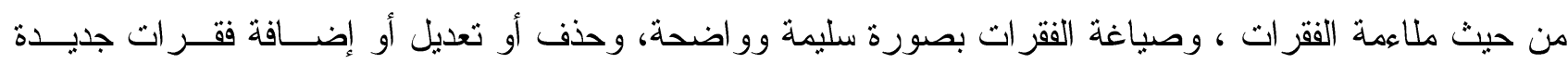

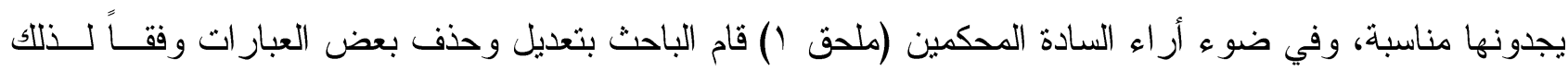

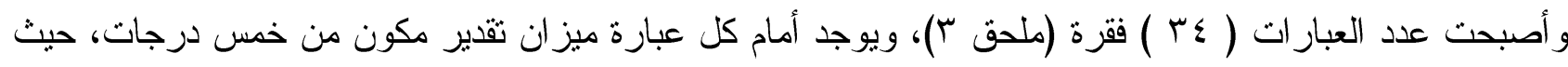

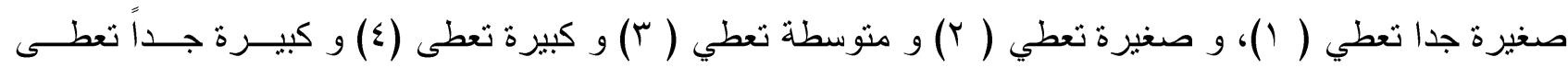
(0).. وبذلك يكون الباحث قد تحقق من الصدق المنطقي للمقياس.

ب- Internal consistency صدق الاتساق الداخلي أ - صدق الاتساق الداخلي لمحور إدارة التغيير:

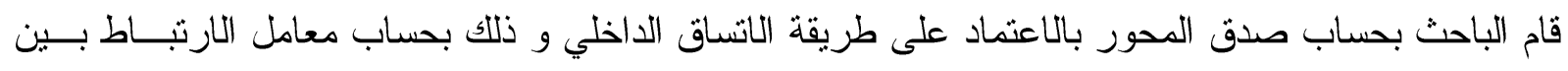

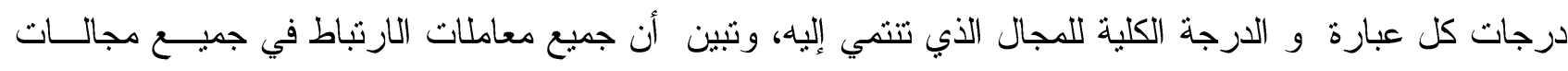

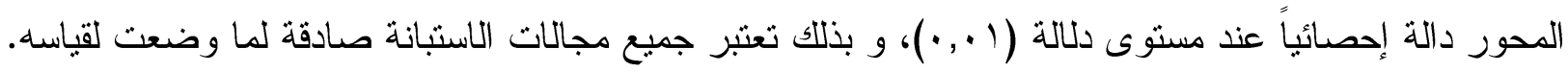

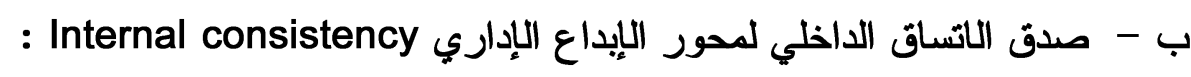

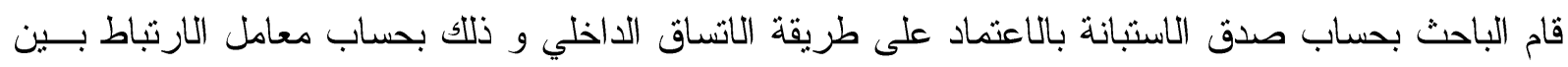

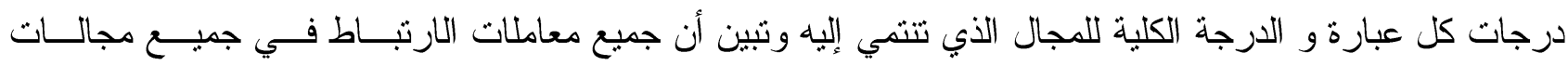

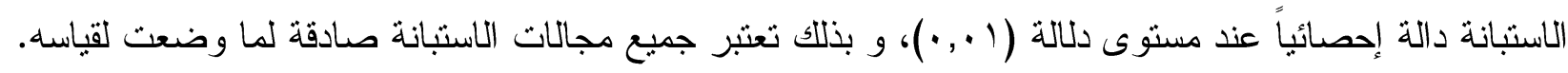

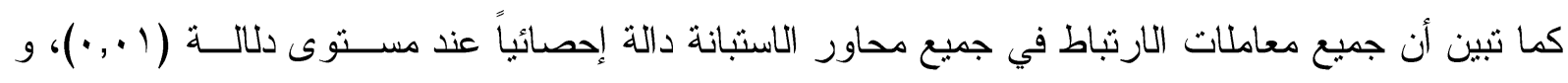

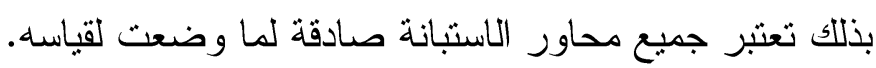

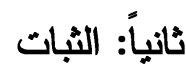

تحقق الباحث من ثبات محور إدارة التغيير من خلال طريقتن وذلك كما يلي:

أ- معامل ألفا كرونباخ Cronbach's Alpha

قام الباحث باستخدام طريقة معامل ألفا كرونباخ لجميع أبعاد و الدرجة الكلية كما في يلي :

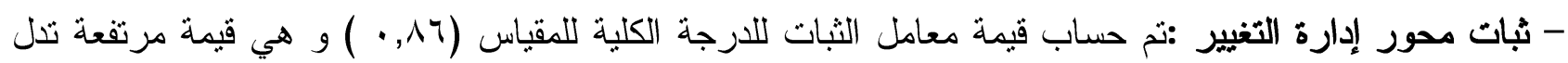

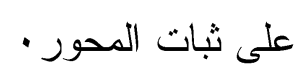
- ثبات محور الإيداع الإداري : ثبات حساب قيمة معامل الثبات للارجة الكلية للمحور (19, · ) ) و هي قيمة مرتفعة تدل

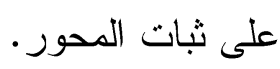
ب- طريقة التجزئة النصفية: طريقة التجزئة النصفية لقياس ثبات محور إدارة التغيير : تم حساب قيمة معامل الارتباط المعدل (سبيرمان بـر اون Spearman Brown مقبول ودال إحصائيًا.

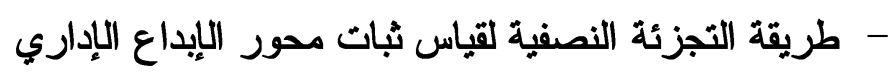

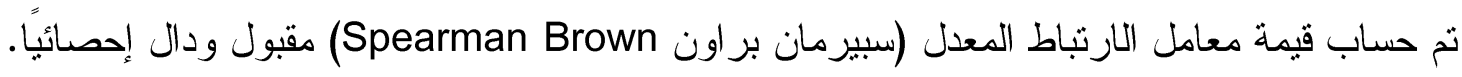


نتائج الدراسة ومناقشتها وتقسير ها

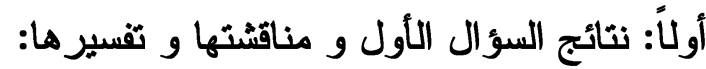
ينص التساؤل الأول على : " ما درجة ممارسة إدارة التغيير لدى قادة مدارس المرحلة الثانوية بمحافظة المخواة من

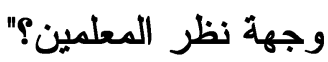
و للإجابة على هذا السؤ ال قام الباحث بحساب المتوسطات و الانحر افات المعيارية، و الجداول التالية توضح ذلك: جدول (V) يوضح مستوى إدارة التغيير لدى مديري المدارس:

\begin{tabular}{|c|c|c|}
\hline مستويات إدارة & المنوسط الحسابي & الأبعاد \\
\hline متوسطة & $r, 10$ & المجال الأول : رؤية المدرسة ورسالتها \\
\hline كبيرة & $r, 7)$ & المجال الثاني : الإبداع و الابتكار العلمي \\
\hline كبيرة & $r, \mathrm{OV}$ & المجال الثالث : ثقافة التغيير التنظيمي و الإداري \\
\hline كبيرة & $r, \uparrow$. & المجال الر ابع : القدوة الحسنة \\
\hline كبيرة & $r, \varepsilon \vee$ & الدرجة الكلية \\
\hline
\end{tabular}

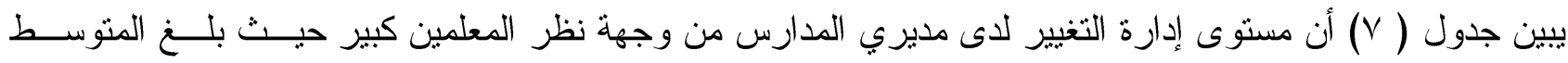

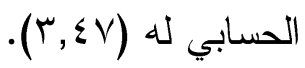

و ترتيب مجالات إدارة التغيير كما يلي:

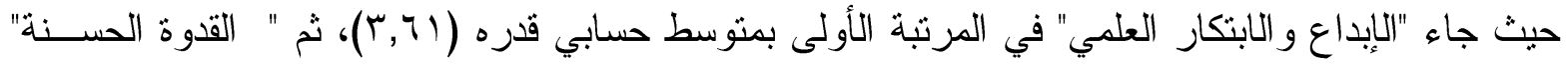

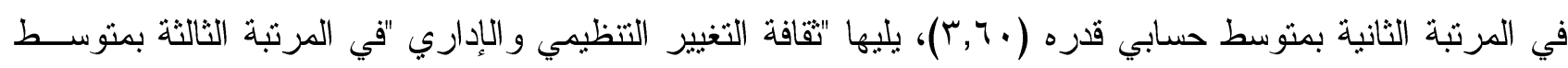

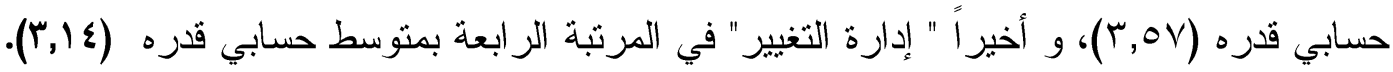

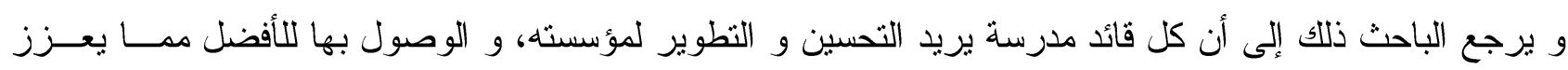

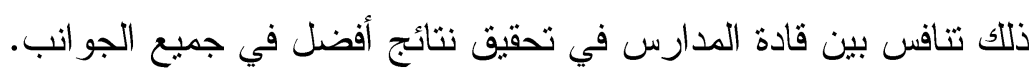

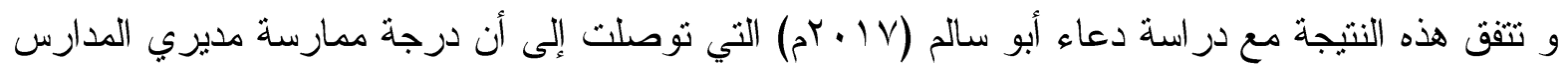

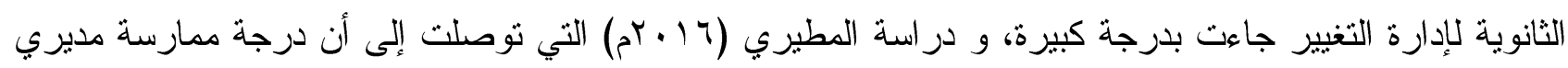

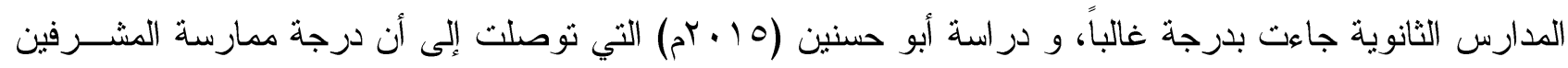

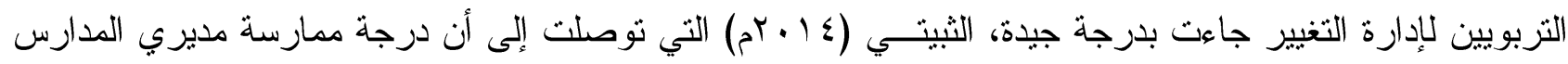

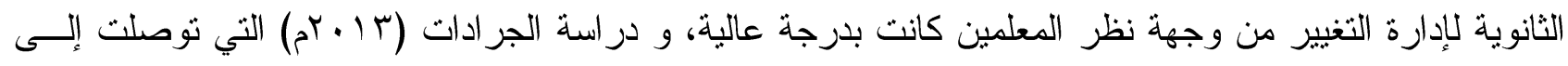

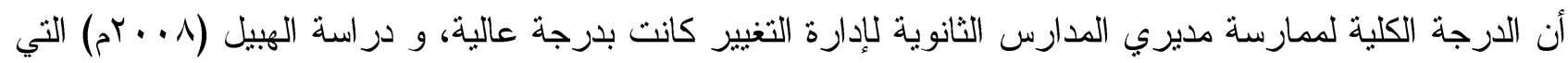

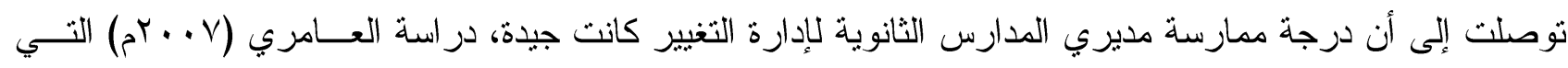

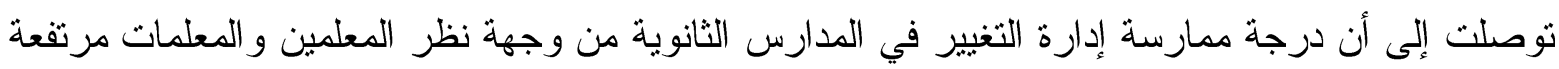

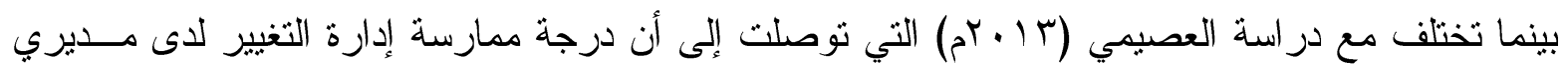

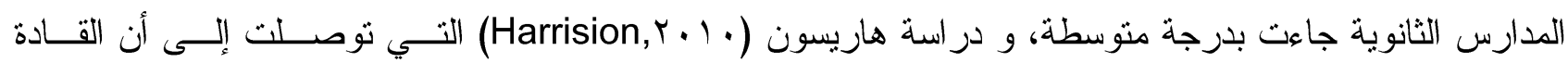
التزبويين في الغالب غير فاعلين في إدارة التغيير في بيئتهم. 
ثانياً: النتائج المتعلقة بالسؤال الثاني و مناقشتها و تقسيرها :

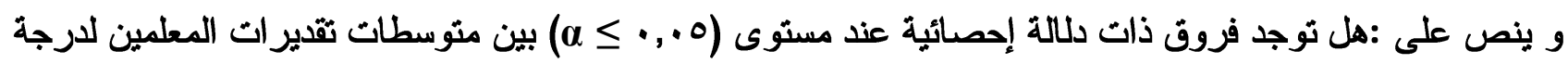

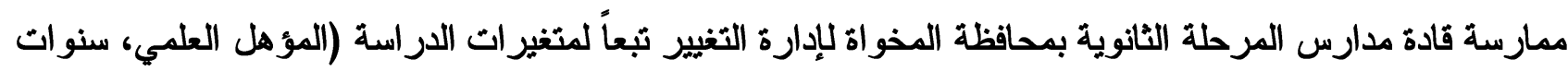

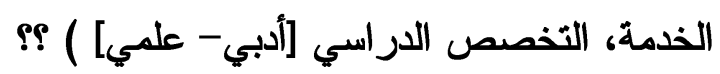
وللإجابة عن هذا السؤ ال، وللكشف عن الدلالة الإحصائية للفروق بين متوسطي تقدير المعلمين لدرجة ممارســة قـادة مدارس المرحلة الثانوية بمحافظة المخواة لإدارة التغيير تبعاً لمتغيرات الدراسة (المؤهل العلمي، ســنو ات الخدمــة، التخصص الدر اسي [أدبي- علمي] )، فقد تم استخدام اختبار ت لعينتين مستقلتين Independent sample T test، وكذلك نم استخدام تحليل التباين أحادي البعد (One-way ANOVA) وذللك على النحو التالي:

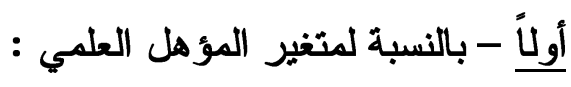
قام الباحث بحساب قيمة (ت) بين متوسطات ثقدير ات المعلمين لدرجة ممارسة قادة مدارس المرحلة الثانوية بمحافظة

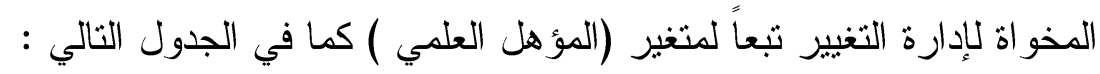
جدول (1) نتائج اختبار (ت) لحساب الفروق بين منوسطات ثقديرات المعلمين لدرجة ممارسة قادة مدارس المرحلة

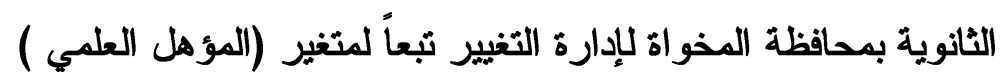

\begin{tabular}{|c|c|c|c|c|c|c|c|}
\hline مسلـــــتوى & قيمة ت & |الحرية & الــانحر اف & الحسابي المتوســــ & العدد & المؤهل العلمي & الأبعاد \\
\hline \multirow[t]{2}{*}{$\cdot 77}$. & \multirow[t]{2}{*}{$\cdots \varepsilon$} & \multirow[t]{2}{*}{ ror } & 1.82 & 7.38 & 347 & بكالوريوس & \multirow{2}{*}{ ورؤيلالتها } \\
\hline & & & 1.77 & 7.38 & 8 & در اسات عليا & \\
\hline \multirow[t]{2}{*}{ •, VYM } & \multirow[t]{2}{*}{ מ97, } & \multirow[t]{2}{*}{ ror } & 1.68 & 7.42 & 347 & بكالوريوس & \multirow[t]{2}{*}{ الإبداع و الابتكار العلمي } \\
\hline & & & 1.51 & 7.00 & 8 & در اسات عليا & \\
\hline \multirow[t]{2}{*}{ سוT } & \multirow[t]{2}{*}{ Q } & \multirow[t]{2}{*}{ ror } & 1.75 & 7.46 & 347 & بكالوريوس & \multirow{2}{*}{ و الإدارية التغيير التظيمي } \\
\hline & & & 1.28 & 7.25 & 8 & در اسات عليا & \\
\hline \multirow[t]{2}{*}{ צח צמ, } & \multirow[t]{2}{*}{ 1, } & \multirow[t]{2}{*}{ ror } & 1.35 & 7.93 & 347 & بكالوريوس & \multirow[t]{2}{*}{ القدوة الحسنة } \\
\hline & & & 1.04 & 7.25 & 8 & در اسات عليا & \\
\hline \multirow[t]{2}{*}{ דצד, } & \multirow[t]{2}{*}{$\cdot, \times \backslash 1$} & \multirow[t]{2}{*}{ ror } & 5.15 & 30.18 & 347 & بكالوريوس & \multirow[t]{2}{*}{ الدرجة الكلية } \\
\hline & & & 4.29 & 28.88 & 8 & در اسات عليا & \\
\hline
\end{tabular}

يتضح من الجدول (^) عدم وجود فروق ذات دلالة إحصائية بين منوســات تقــدير ات المعلمـين لدرجــة ممارسة قادة مدارس المرحلة الثانوية بمحافظة المخو اة لإدارة التغيير تبعاً لمتغير (المؤهل العلمــي ) فــي : رؤيـــة المدرسة ورسالتها ، الإبداع و الابتكار العلمي ، ثقافة التغيير التنظيمي و الإداري ، القدوة الحسنة ، الدرجة الكلية حيــث 


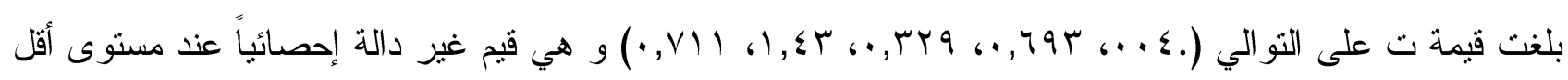
من (.0. (·)

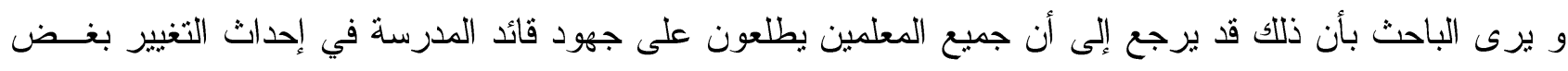

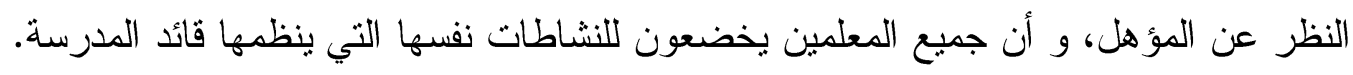
ثانياً - بالنسبة لسنوات الخبرة

قام الباحث بحساب تحليل التباين الأحادي الاتجاه بين متوسطات درجات عينة البحث تبعاً لمتغير سنوات الخبرة كمـــ

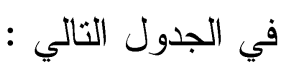
جدول (9) نتائج تحليل الثباين الأحادي الاتجاه لدلالة الفروق بين مثتوسطات درجات عينة البحث في تقديرات

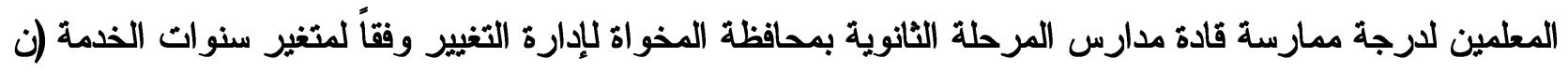
(roo=

\begin{tabular}{|c|c|c|c|c|c|c|}
\hline مستوي الدلالة & قيمة ف & متوسط المربعات & الحرية & المربعات & مصدر التباين & المحاور \\
\hline \multirow{3}{*}{$\cdot, \cdots$} & \multirow{3}{*}{16.210} & 49.14 & 2 & 98.29 & بين الهجموعات & \multirow{3}{*}{ ورؤيــــة المدرســــة (1) } \\
\hline & & 3.03 & 352 & 1067.13 & داخل المجموعات & \\
\hline & & & 354 & 1165.42 & المجموع & \\
\hline \multirow{3}{*}{$\cdot, 1$. } & \multirow{3}{*}{2.278} & 6.34 & 2 & 12.67 & بين المجمو عات & \multirow{3}{*}{$\begin{array}{c}\text { الإبداع و الابتكار } \\
\text { العلمي }\end{array}$} \\
\hline & & 2.78 & 352 & 978.92 & داخل المجموعات & \\
\hline & & & 354 & 991.59 & الهجموع & \\
\hline \multirow{3}{*}{$\cdot, \cdot 1 \leqslant$} & \multirow{3}{*}{4.338} & 12.92 & 2 & 25.83 & بين المجموعات & \multirow{3}{*}{$\begin{array}{c}\text { التقافة التغيير } \\
\text { التظيمي و الإداري }\end{array}$} \\
\hline & & 2.98 & 352 & 1048.06 & داخل المجموعات & \\
\hline & & & 354 & 1073.89 & المجموع & \\
\hline \multirow{3}{*}{$\cdot, \ldots$} & \multirow{3}{*}{5.433} & 9.56 & 2 & 19.12 & بين المجموعات & \multirow{3}{*}{$\begin{array}{c}\text { القدوة الحسنة } \\
\text { الحنة }\end{array}$} \\
\hline & & 1.76 & 352 & 619.51 & داخل المجموعات & \\
\hline & & & 354 & 638.63 & المجموع & \\
\hline \multirow{3}{*}{$\cdot, \ldots$} & \multirow{3}{*}{10.204} & 255.58 & 2 & 511.16 & بين المجموعات & \multirow[t]{3}{*}{ الدرجة الكلية } \\
\hline & & 25.05 & 352 & 8816.63 & داخل المجموعات & \\
\hline & & & 354 & 9327.79 & المجموع & \\
\hline
\end{tabular}

يظهر الجدول (9) وجود فروق ذات دلالة إحصائية تعزى لسنوات الخدمة على (رؤية المدرسة ورسـالتها،

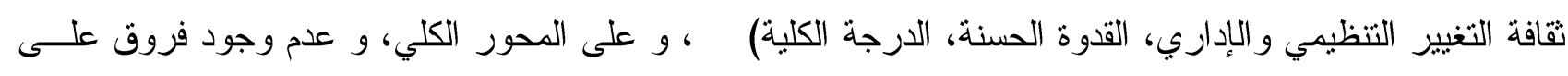
: إلإبداع و الابتكار العلمي. ولتحديد اتجاهات الفروق بين المجموعات تم استخدام اختبار (شيفيه Schefee) البعـدي للمقارنـــة المتعـددة بـين

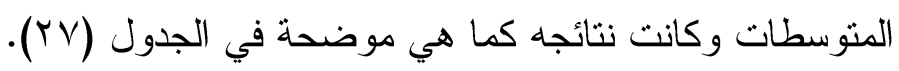


جدول (• (): نتائج اختبار شيفيه لتحديد اتجاهات الفروق بين منوسطات درجات عينة البحث في ثقديرات المعلمين لدرجة ممارسة قادة مدارس المرحلة الثانوية بمحافظة المخواة لإدارة التغيير وفقاً لمتغير سنوات الخدمة (ن = هـم)

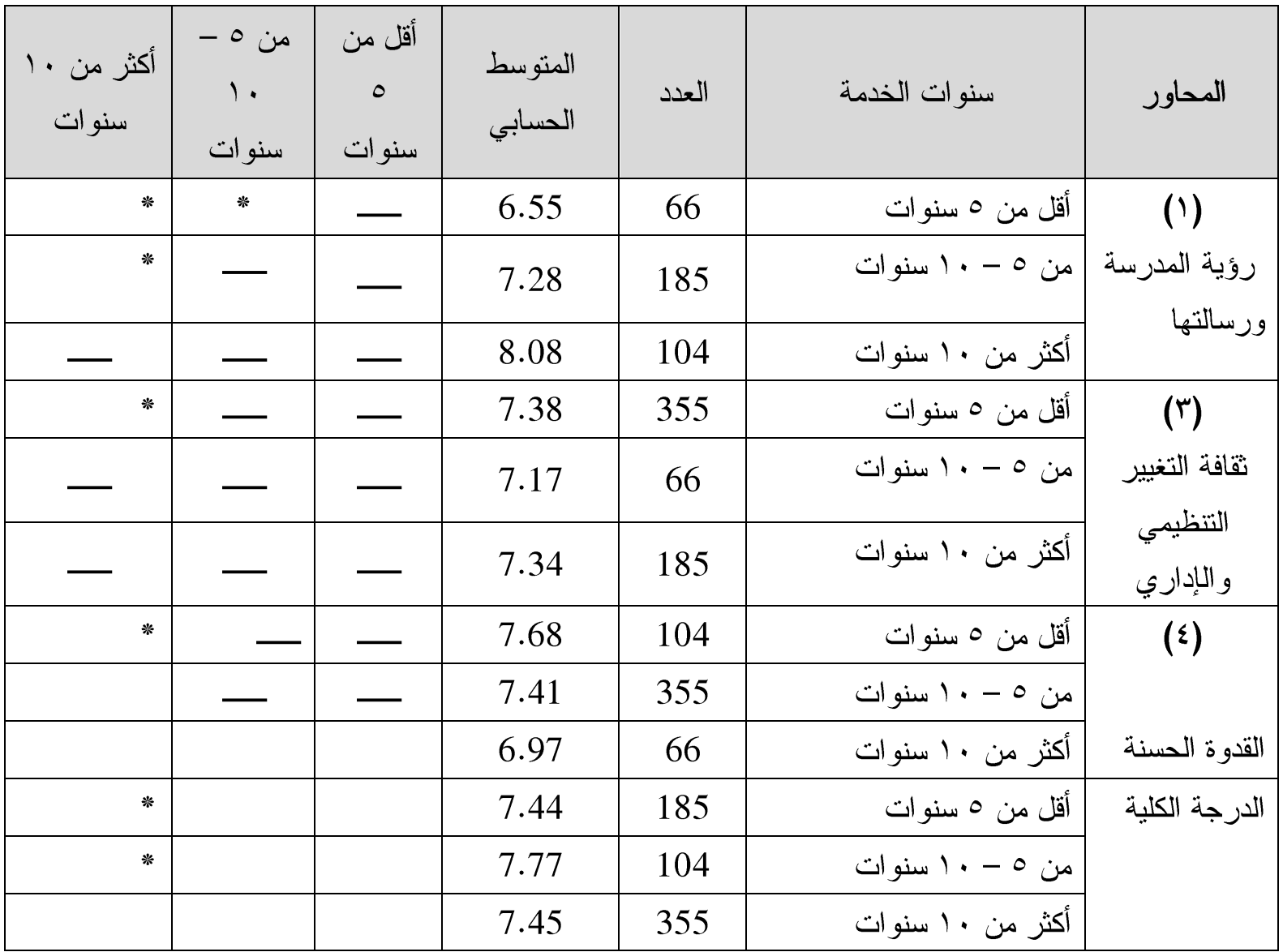

يتضح من الجدول ( • () أن هناك فروقاً دالة إحصائيًا في إدارة التغيير تعزى لمتغير سنوات الخدمة، ويفسر الباحث ذللك بأن المعلمين ذوي الخبرة الطويلة لديهم القدرة على تقبل التغيير و العمل على إنجاحه و الحد من معوقاته بدرجــة

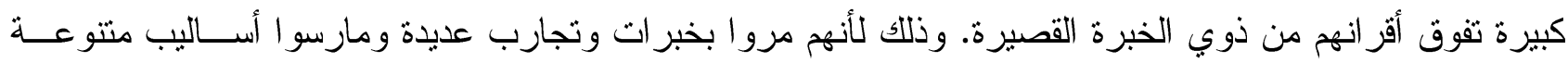

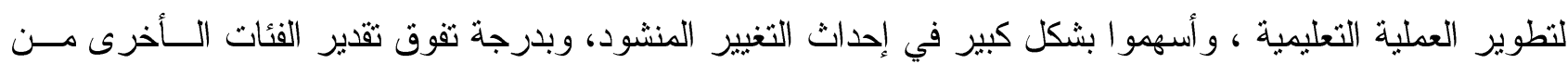
المعلمين ذوي الخبرة القصيرة.

المعلمون الذين لايهم الخبرة في التعليم يرون أن العنصر الأساسي في عملية إدارة التغيير يتمثل في ممارسة

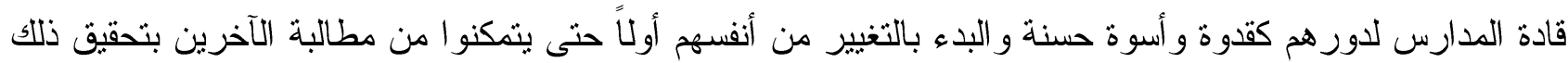
التغيير المنشود. و تثفق هذه النتيجة جزئيا مع در اسة الثبيتـي (ع ا • rم) التي توصلت إلى ووجود فروق ذات دلالة إحصائية تبعاً لسنو ات الخبرة ولصالح الذين خبرتهم ه سنو ات فأقله و دراسة الهبيل (^ . . rم) التي توصلت إلى عدم وجود فروق ذات دلالة إحصائية في تقديرات المعلمــين لمدى ممارسة مديري المدارس الثانوية تعزى لمتغير سنوات الخدمة في مجال الرؤية المستقبلية للمدرســة ومجــال تشجيع الإبداع و الابتكار لدى العاملين، ووجود فروق ذات دلالة إحصائية نعزى لمتغير سنوات الخدمة في مجال القدوة و الأسوة الحسنة ومجال الثقافة التنظيمية الداعمة للنغيير وكانت الدلالة لصالح أصحاب سنوات الخبرة الطويلة. 
و تختلف هذه النتيجة مع در اسة المطيري (7 ( • rم) التي توصلت إلى عدم وجود فروق ذات دلالة إحصائية في درجة ممارسة مديري المدارس الثانوية لإدارة التغيير من وجهة نظر المعلمين تعزى لسنوات الخدمة، و در اســـة أبو حسنين (10 • rم) التي توصلت إلى عدم وجود فروق ذات دلالة إحصائية في اســتجابات أفــر اد العينـــة لارجـــة

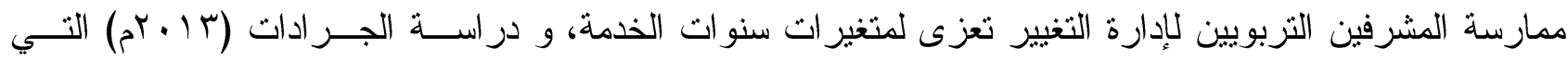
توصلت إلى عدم وجود فروق ذات دلالة إحصائية في ممارسة مديري المدارس الثانوية لإدارة التغيير تبعــاً لمتغيـر الخبرة العملية، و در اسة شقورة (r ا • rم) الثي ثوصلت إلى عدم وجود فروق ذات دلالة إحصــائية بــين ثقـديرات

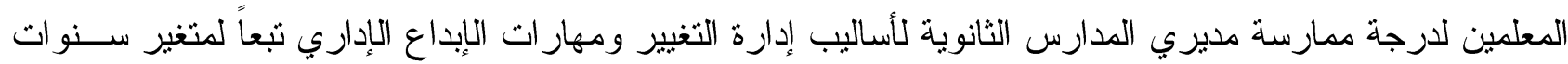
الخدمة .

ثالثاًا- بالنسبة لمتغير التخصص الدراسي: للكثف عن الدلالة الإحصائية للفروق بين متوسطي ثقدير معلمي المدارس الثانوية لدرجــة ممارســة قــادة

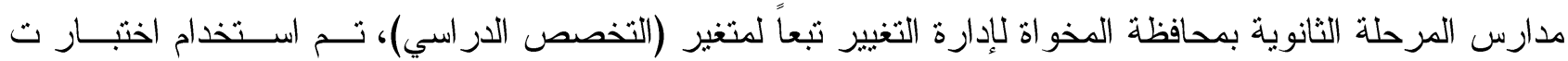

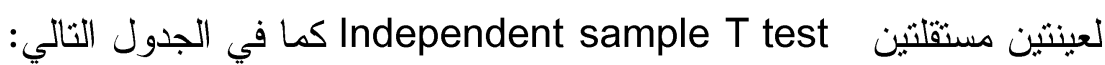
جدول ( II) نتائج اختبار (ت) لحساب الفروق بين منوسطات ثقديرات المعلمين لدرجة ممارسة قادة مدارس

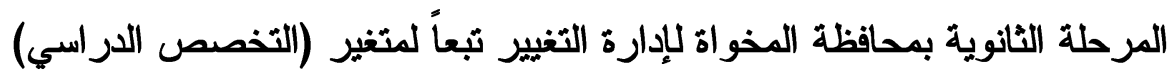

\begin{tabular}{|c|c|c|c|c|c|c|c|}
\hline الدلالة & فيمة ت & الحرية & الـــانحر اف المعياري & الحسابي المتوســــ & العدد & 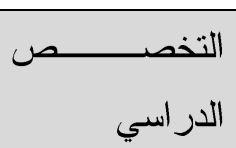 & الأبعاد \\
\hline \multirow[t]{2}{*}{$\cdot, 17$} & \multirow[t]{2}{*}{1.39} & \multirow[t]{2}{*}{ ror } & 1.87 & 7.49 & 200 & علوم طبيعية & \multirow{2}{*}{ 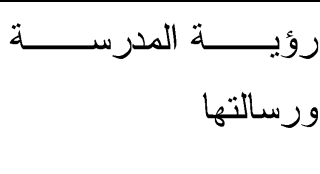 } \\
\hline & & & 1.74 & 7.23 & 155 & علوم شرعية & \\
\hline \multirow[t]{2}{*}{$\cdot, r$} & \multirow[t]{2}{*}{1.27} & \multirow[t]{2}{*}{ ror } & 1.72 & 7.51 & 200 & علوم طبيعية & \multirow[t]{2}{*}{ الإبداع و الابتكار العلمي } \\
\hline & & & 1.60 & 7.28 & 155 & علوم شرعية & \\
\hline \multirow[t]{2}{*}{$\cdot, Y Y$} & \multirow[t]{2}{*}{1.22} & \multirow[t]{2}{*}{ ror } & 1.82 & 7.55 & 200 & علوم طبيعية & \multirow{2}{*}{ و الإدارية التغيير التنظيمي } \\
\hline & & & 1.63 & 7.32 & 155 & علوم شر عية & \\
\hline \multirow[t]{2}{*}{$\cdot, \cdot 1$} & \multirow[t]{2}{*}{2.52} & \multirow[t]{2}{*}{ ror } & 1.42 & 8.08 & 200 & علوم طبيعية & \multirow[t]{2}{*}{ القدوة الحسنة } \\
\hline & & & 1.21 & 7.72 & 155 & علوم شرعية & \\
\hline \multirow[t]{2}{*}{$\cdot, \cdot \leq$} & \multirow[t]{2}{*}{1.98} & \multirow[t]{2}{*}{ ror } & 5.49 & 30.63 & 200 & علوم طبيعية & \multirow[t]{2}{*}{ الدرجة الكلية } \\
\hline & & & 4.58 & 29.54 & 155 & علوم شرعية & \\
\hline
\end{tabular}

يتضح من الجدول (1') وجود فروق ذات دلالة إحصائية بين منوسطات تقدير ات المعلمين لدرجة ممارســة

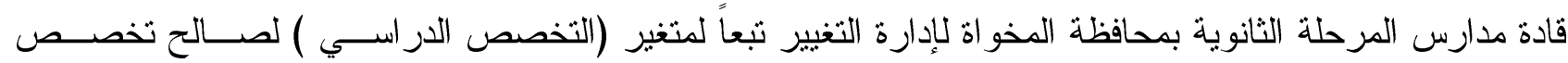

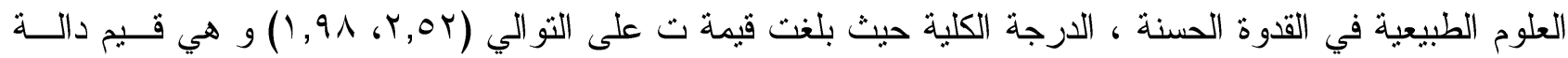
إحصائياً عند مستوى أقل من (0., •)، و عدم وجود فروق في : رؤية المدرسة ورسالتها، الإبداع و الابتكار العلمـي، 


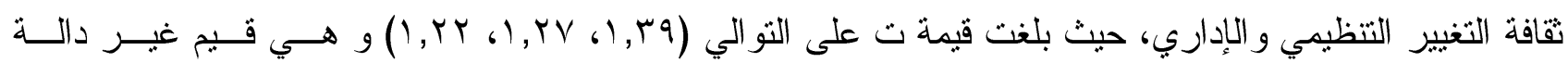
إحصائياً عند مستوى أقل من (0. •. •).

و هنا يرى الباحث أن ذلك قد يرجع إلى أن جميع المعلمين أبا كان تخصصهم الدراسـي يخضــعون لجهــة و احدة و هي وزارة التعليم، و هي التي تضع السياسات و تقدم الدورات التربوية. كما أن في موضوع رؤية المدرسة

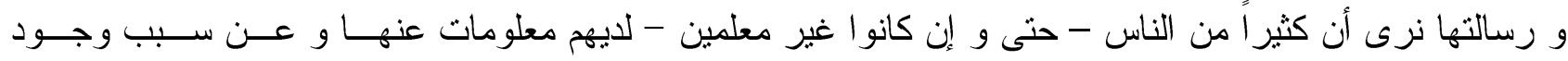
المدرسة و عملها.

و تتفق هذه النتيجة مع در اسة المطيري (T ( • r م) التي توصلت إلى ووجود فروق ذات دلالة إحصائية وفـق متغير ات: المؤهل العلمي، ونوع المؤهل.

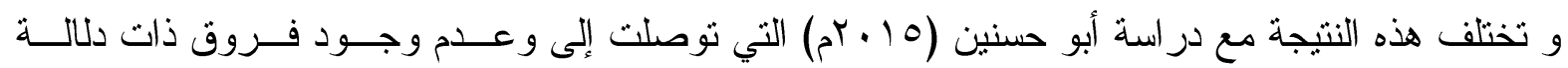
إحصائية في استجابات أفر اد العينة لدرجة ممارسة المشرفين التربوبين لإدارة التغيير تعزى لمتغير المؤهل العلمي، و و در اسة الثبيتـي (ع ا • rم) التي توصلت إلى عدم وجود فروق ذات دلالة إحصائية حول درجات ممارســة مـديري

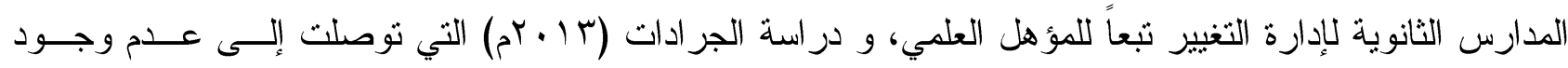
فروف ذات دلالة إحصائية في ممارسة مديري المدارس الثانوية لإدارة التغيير تبعاً لمتغير المؤهل العلمي،

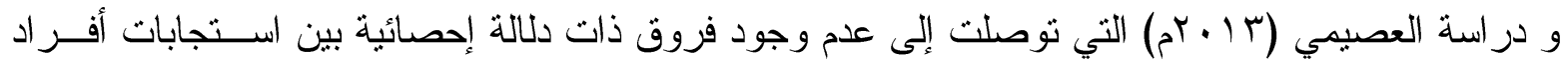
العينة حول درجة ممارسة مديري المدارس الثانوية لإدارة التغيير تعزى للمؤهل العلمي، و در اسة شـقورة (r أ. rم) التي توصلت إلى عدم وجود فروق ذات دلالة إحصائية بين ثقدير ات المعلمين لدرجــة ممارســة مــديري المــدارس الثانوية لأساليب إدارة التغيير ومهار ات الإبداع الإداري تبعاً لمتغير التخصص.

ثالثاً: نتائج السؤال الثالث و مناقشتها و تفسير ها: ينص السؤال الثالث على : " ما مستوى الإبداع لدى قادة مدارس المرحلة الثانوية بمحافظة المخواة من وجهة نظر المعلمين؟" و للإجابة عن هذا السؤال نم حساب المتوسطات الانحر افات المعيارية، و الجداول التالية توضح ذلك: مستوى الإيداع الإداري لدى مديري المدارس: جدول (Y I ) مستويات الإبداع الإداري و أبعاده

\begin{tabular}{|c|c|c|}
\hline مستويات الإبداع & المتوسط الحسابي & 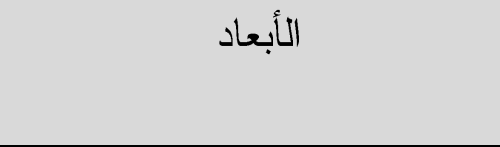 \\
\hline 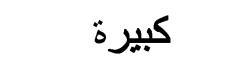 & r,V & البعد الأول: الأصالة \\
\hline 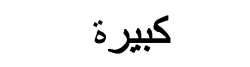 & 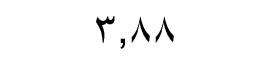 & البعد الثاني : الطلاقة \\
\hline كبيرة & r,ı० & البعد الثالث : المرونة \\
\hline 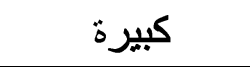 & r,人 & البعد الر ابع : الحساسية بالمشكلات \\
\hline 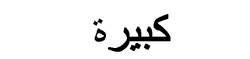 & $\uparrow, \wedge \varepsilon$ & البعد الخامس : المخاطرة \\
\hline 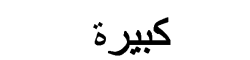 & r, r & الدرجة الكلية \\
\hline
\end{tabular}


يبين جدول (r ا) أن مستوى الإبداع الإداري لاى مديري المدارس من وجهة نظر المعلمين مرتفع حيث بلغ المتوسط

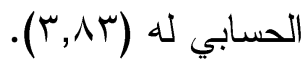

و يتضح أن مستوى الإيداع لاى قادة مدارس المرحلة الثانوية بمحافظة المخو اة من وجهة نظــر المعلمـين

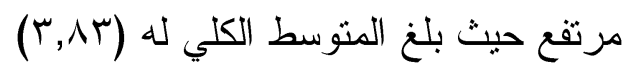

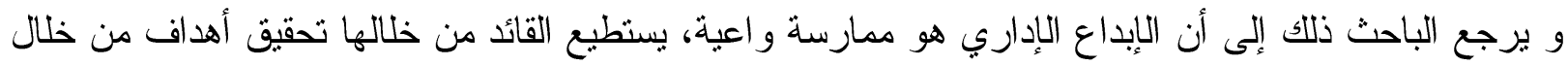

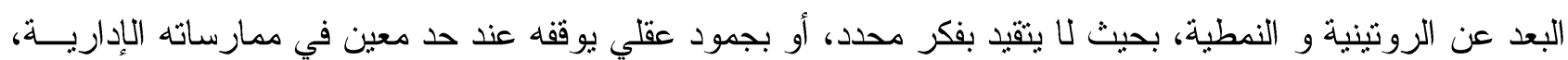

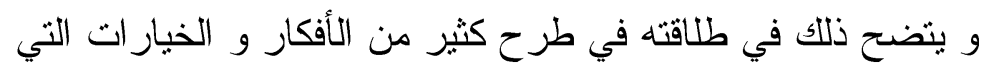

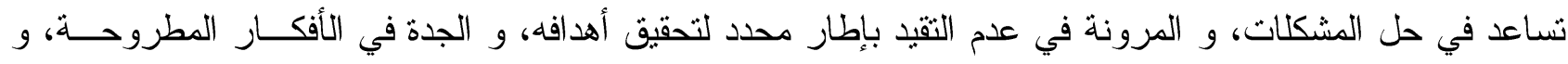

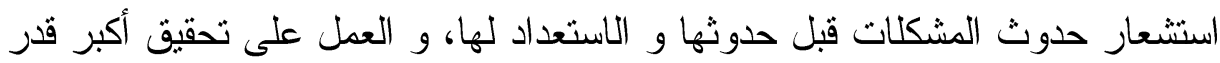
من الاستفادة من المعطيات المتاحة و التغلب على العقبات للوصول إلى أفضل النتائج، مما يعكس لفان القدرة على التغيير.

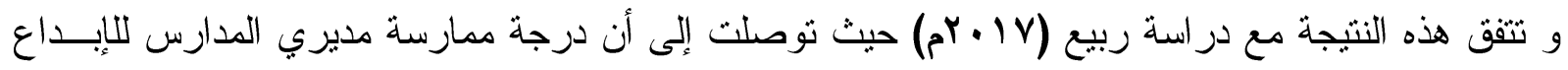

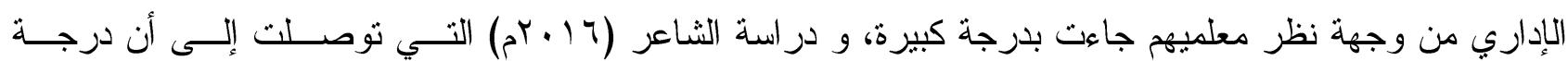

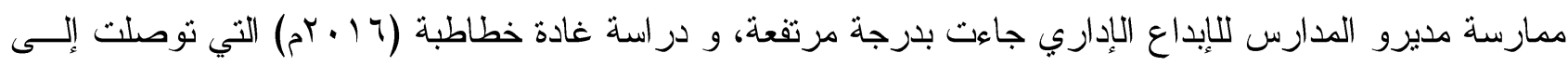

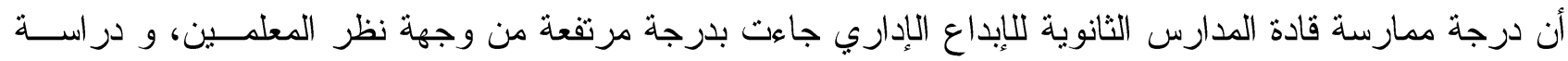

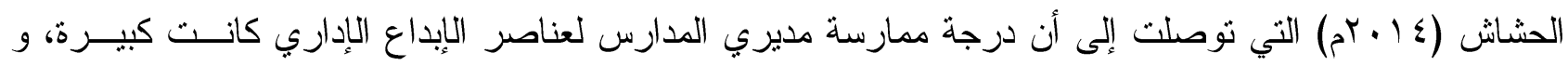

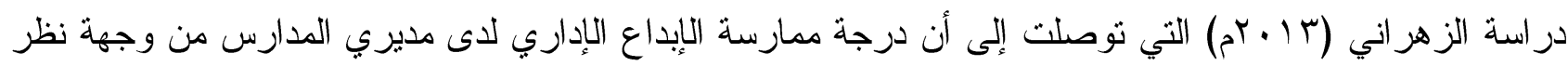

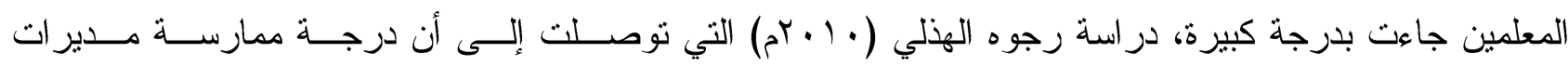

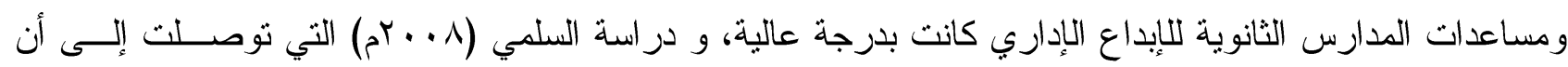

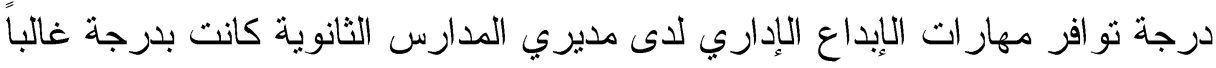

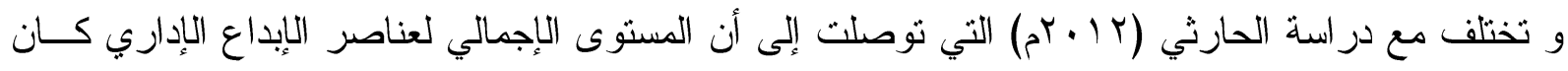

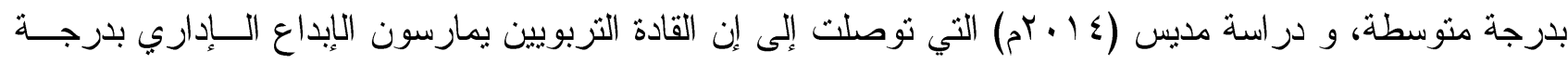
منوسطة

رابعاً:النتائج المتعلقة بالسؤال الرابع و مناقشتها و تثفير ها:

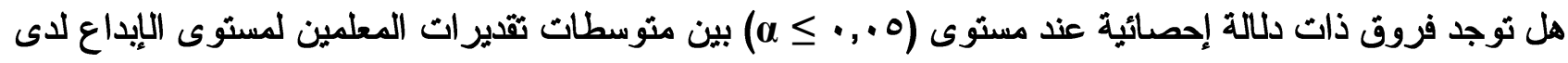

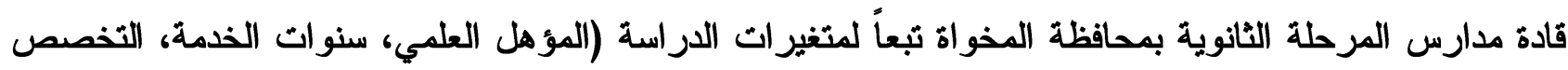

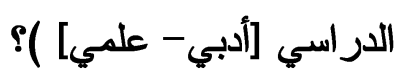
وللإبابة عن هذا السؤ ال، وللكثتف عن الدلالة الإحصائية للفروق بين منوسطات تقــير المعلمـين لمســتوى

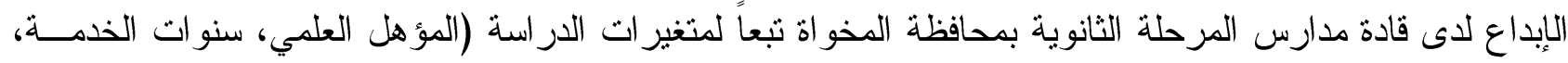

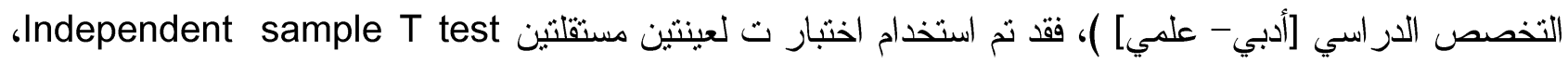
وكذلك تم استخدام تحليل التباين أحادي البعد (One-way ANOVA) وذلك على النحو التالي: تلفي أولاً : بالنسبة لمتغير المؤهل العلمي: 
قام الباحث بحساب قيم (ت) متوسطات تقدير ات المعلمين لمستوى الإبداع لاى قادة مدارس المرحلة الثانوية بمحافظـــة المخو اة تبعاً لمتغير (المؤهل العلمي ) كما في الجدول التالي:

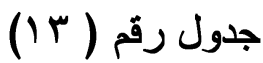

نتائج اختبار (ت) لحساب الفروق بين متوسطات تقديرات المعلمين لمستوى الإبداع لدى قادة مدارس المرحلة الثانوية

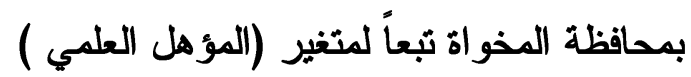

\begin{tabular}{|c|c|c|c|c|c|c|c|}
\hline الدلالة مســـتـوى & قيمة ت & درجـــة & المعياري & المستوســـ الحسب & العدد & المؤهل & الأبعاد \\
\hline \multirow[t]{2}{*}{ • } & \multirow[t]{2}{*}{ •, Y } & \multirow[t]{2}{*}{ ror } & 1.44 & 7.61 & 347 & بكالوريوس & \multirow[t]{2}{*}{ الأصالة } \\
\hline & & & 1.93 & 7.50 & 8 & در اسات عليا & \\
\hline \multirow[t]{2}{*}{$\cdot, 7 \wedge$} & \multirow[t]{2}{*}{$\cdot, \leqslant r$} & \multirow[t]{2}{*}{ ror } & 1.44 & 7.78 & 347 & بكالوريوس & \multirow[t]{2}{*}{ الطلاقة } \\
\hline & & & 1.77 & 8.000 & 8 & در اسات عليا & \\
\hline \multirow[t]{2}{*}{$\cdot, \mathrm{VA}$} & \multirow[t]{2}{*}{$\cdot, r \wedge$} & \multirow[t]{2}{*}{ ror } & 1.39 & 7.74 & 347 & بكالوريوس & \multirow[t]{2}{*}{ المرونة } \\
\hline & & & .99 & 7.88 & 8 & در اسات عليا & \\
\hline \multirow[t]{2}{*}{$\cdot, 17$} & \multirow[t]{2}{*}{$1, \varepsilon r$} & \multirow[t]{2}{*}{ سor } & 1.35 & 7.93 & 347 & بكالوريوس & \multirow[t]{2}{*}{ الحساسية بالمشكلات } \\
\hline & & & 1.04 & 7.25 & 8 & در اسات عليا & \\
\hline \multirow[t]{2}{*}{$\cdot, \varepsilon$. } & \multirow[t]{2}{*}{$\cdot, \wedge \varepsilon$} & \multirow[t]{2}{*}{ ror } & 1.35 & 7.78 & 347 & بكالوريوس & \multirow[t]{2}{*}{ المخاطرة } \\
\hline & & & 1.19 & 7.38 & 8 & در اسات عليا & \\
\hline \multirow[t]{2}{*}{$\cdot, 70$} & \multirow[t]{2}{*}{$\cdot, \leqslant 0$} & \multirow[t]{2}{*}{ ror } & 5.26 & 38.85 & 347 & بكالوريوس & \multirow[t]{2}{*}{ الدرجة الكلية } \\
\hline & & & 4.96 & 38.00 & 8 & در اسات عليا & \\
\hline
\end{tabular}

يتضح من الجدول (r (1) عدم وجود فروق ذات دلالة إحصائية بين متوسطات تقدير ات المعلمـين لمسـتوى

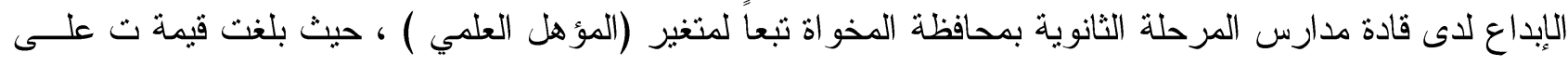

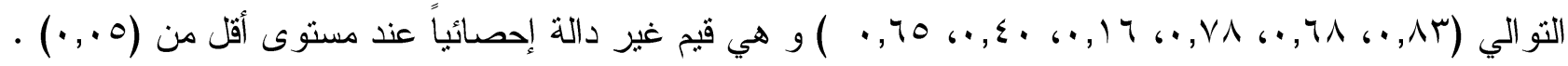
ويمكن تقسير سبب ذلك إلى تشابه الظروف المدركة من قبل جميع المعلمين للممارسات التي يقوم بها قادة المــدارس لإدارة التغيير بغض النظر عن نوع المؤهل.

و تتفق هذه النتيجة مع در اسة مديس (ع ا • rم) التي توصلت إلى عدم وجود فروق في ثقدير ات أفر اد العينــة

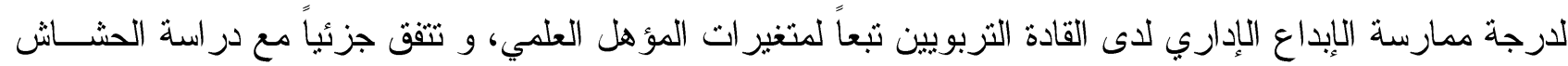
(ع ( • بم) التي نوصلت إلى عدم وجود فروق نعزى لمتغير المؤهل العلمي في جميع المجالات ما عدا مجال المرونة فوجدت فروق لصالح البكالوريوس، و در اسة الحارثي (r ( • rم) التي توصلت إلى عدم وجــود فـــروق ذات دلالـــة إحصائية بين متوسطات استجابات أفر اد العينة حول مستوى الإبداع الإداري لدى مديري المدارس الثانوية تبعاً لمتغير المؤهل العلمي، و در اسة رجوه الهذلي (•( • (r) التي توصلت إلى عدم وجود فروق ذات دلالة إحصائية في ممارسة الإبداع الإداري تعزى للمؤهل العلمي. 
و تختلف هذه النتيجة مع دراسة غادة خطاطبة (7 آم) التي توصلت إلى وجود فروق ذات دلالة إحصائية

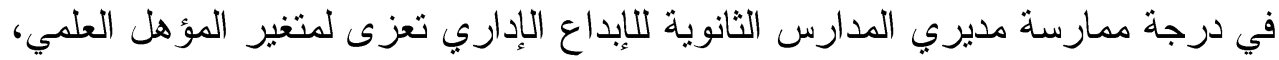

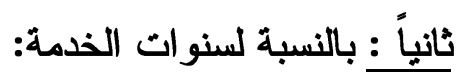
One Way ANOVA قام الباحث باستخدام أسلوب تحليل الثباين الأحادي جدول ( ع () مصدر الثباين ومجموع المربعات ودرجات الحرية ومنوسط المربعات وقيمة "ف" ومستوى الدلالة تعزى لمتغير سنوات الخدمة.

\begin{tabular}{|c|c|c|c|c|c|c|}
\hline مستوي الدلالة & قيمة ف & منوسط المربعات & درجة & المربعات & مصدر التباين & المحاور \\
\hline \multirow{3}{*}{$\cdot, .91$} & \multirow{3}{*}{2.339} & 4.868 & 2 & 9.735 & بين المجموعات & \multirow{3}{*}{ الأصلالة (1) } \\
\hline & & 2.081 & 352 & 732.620 & داخل المجموعات & \\
\hline & & & 354 & 742.355 & المجموع & \\
\hline \multirow{3}{*}{$\cdot, \cdot 1 r$} & \multirow{3}{*}{4.485} & 9.234 & 2 & 18.468 & بين المجمو عات & \multirow{3}{*}{$\begin{array}{c}\text { (Y) } \\
\text { الطلاقة }\end{array}$} \\
\hline & & 2.059 & 352 & 724.687 & داخل المجموعات & \\
\hline & & & 354 & 743.155 & المجموع & \\
\hline \multirow{3}{*}{$\cdot, \cdots 1$} & \multirow{3}{*}{7.208} & 13.418 & 2 & 26.837 & بين المجمو عات & \multirow{3}{*}{$\begin{array}{c}\text { المرونة } \\
\text { آس }\end{array}$} \\
\hline & & 1.862 & 352 & 655.321 & داخل المجمو عات & \\
\hline & & & 354 & 682.158 & المجموع & \\
\hline \multirow{3}{*}{$\cdot, \cdots 0$} & \multirow{3}{*}{5.433} & 9.562 & 2 & 19.124 & بين المجموعات & \multirow{3}{*}{ 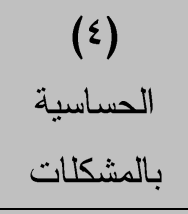 } \\
\hline & & 1.760 & 352 & 619.507 & داخل المجمو عات & \\
\hline & & & 354 & 638.631 & المجموع & \\
\hline \multirow{3}{*}{$\bullet, \bullet \varepsilon}$. & \multirow{3}{*}{3.239} & 5.828 & 2 & 11.655 & بين المجموعات & \multirow{3}{*}{$\begin{array}{c}\text { المخاطرة } \\
\text { (0) }\end{array}$} \\
\hline & & 1.799 & 352 & 633.404 & داخل المجمو عات & \\
\hline & & & 354 & 645.059 & المجموع & \\
\hline \multirow{3}{*}{$\cdot, \cdots 1$} & \multirow{3}{*}{7.383} & 196.359 & 2 & 392.718 & بين المجموعات & \multirow[t]{3}{*}{ لارجة الكلية } \\
\hline & & 26.596 & 352 & 9361.800 & داخل المجموعات & \\
\hline & & & 354 & 9754.518 & المجموع & \\
\hline
\end{tabular}

يظهر الجدول (ع () وجود فروق ذات دلالة إحصائية تعزى لسنوات الخدمة على أبعاد الإبداع الإداري فيمـا. عدا بعدي (الأصالة، الحساسية بالمشكلات ) و وجود فروف أيضاً على المحور الكلي للإِبداع الإداري.

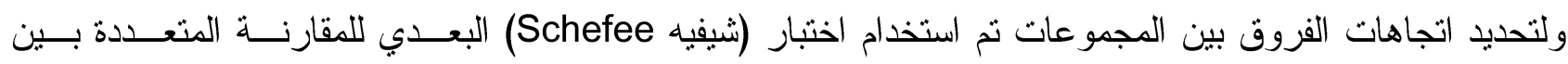
المتوسطات وكانت نتائجه كما هي موضحة في التالي: جدول ( 10 ) نتائج اختبار شيفيه البعدي لاتجاه صالح الفروق الدالة إحصائيا لمتغير سنوات الخدمة 


\begin{tabular}{|c|c|c|c|c|c|c|}
\hline سنو من من ات & سن من - . & سنو ات من & المنوسط الحسابي & 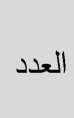 & سنوات الخدمة & المحاور \\
\hline \multirow[t]{3}{*}{$*$} & & & 7.45 & 66 & أقل من ه سنو ات & \multirow{3}{*}{ الطلاقة } \\
\hline & & & 7.73 & 185 & من 0 - . اسنوات & \\
\hline & & & 8.11 & 104 & أكثر من · ( سنوات & \\
\hline$*$ & $*$ & & 7.24 & 66 & أقل من ه سنوات & \multirow{3}{*}{$\begin{array}{c}\text { المرونة } \\
\text { آمّ }\end{array}$} \\
\hline \multirow[t]{2}{*}{ * } & & & 7.74 & 185 & من 0 - · سنوات & \\
\hline & & & 8.06 & 104 & أكثر من · ـ سنو ات & \\
\hline * & & & 7.67 & 66 & أقل من ه سنوات & \multirow{3}{*}{$\begin{array}{l}\text { الحساسية } \\
\text { المشكات } \\
\text { الحساسل }\end{array}$} \\
\hline \multirow[t]{2}{*}{ * } & & & 7.81 & 185 & من 0 - ، اسنو ات & \\
\hline & & & 8.27 & 104 & أكثر من · ( سنوات & \\
\hline$*$ & & & 37.42 & 66 & أقل من ه سنوات & \multirow[t]{3}{*}{ الدرجة الكلية } \\
\hline \multirow[t]{2}{*}{$*$} & & & 38.48 & 185 & من 0 - . 1 سنوات & \\
\hline & & & 40.35 & 104 & أكثر من · ( سنوات & \\
\hline
\end{tabular}

يتضح من الجدول (10 ) أن هناك فروقاً دالة إحصائيًا في الإبداع الإداري تعزى لمتغير سنو ات الخدمة و تتفق هــذهـ النتيجة مع در اسة غادة خطاطبة (7 ( • rم) التي توصلت إلى وجود فروق ذات دلالة إحصائية في درجــة ممارســـة مديري المدارس الثانوية للإبداع الإداري تعزى لمتغير سنوات الخبرة ولصالح من لديه خبرة عشر سنوات فأقل.

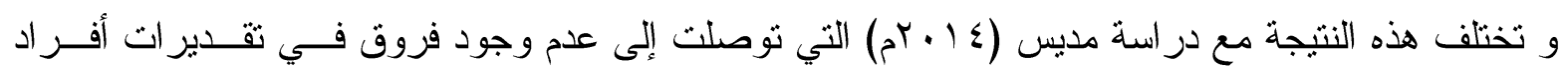

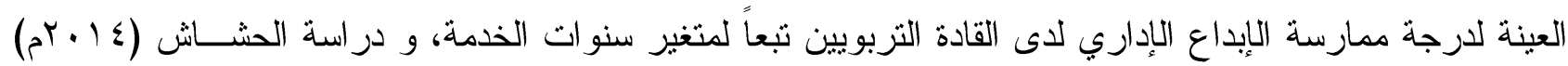

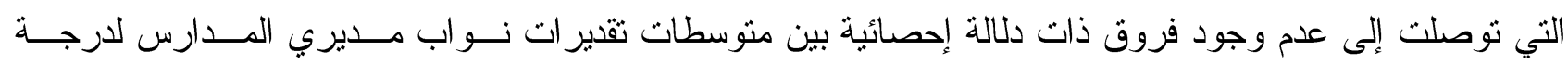

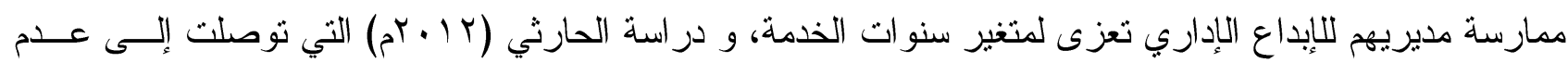
وجود فروق ذات دلالة إحصائية بين متوسطات استجابات أفر اد العينة حول مستوى الإبداع الــإداري لــدى مــديري

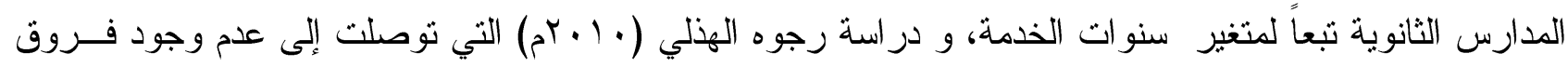
ذات دلالة إحصائية في ممارسة الإبداع الإداري تعزى لسنوات الخبرة. ثُالثاً: بالنسبة للتخصص الدر اسي: للكثف عن الدلالة الإحصائية للفروق بين متوسطات تقدير معلمي المدارس الثانوية بمحافظة المخو اة لمستوى الإبداع لدى قادة مدارس المرحلة الثانوية تبعاً لمتغير (التخصص الدراسي)، فقد تـــ اســتخدام اختبــار ت لعينتـين

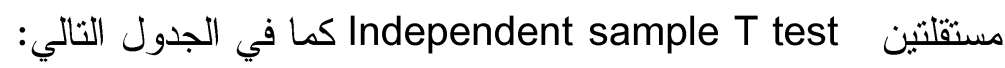
جدول (17) نتائج اختبار (ت) (T-Test) لحساب الفروق بين متوسطات ثقدير ات المعلمين لمستوى الإيداع لدى قادة مدارس

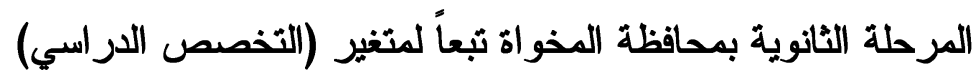




\begin{tabular}{|c|c|c|c|c|c|c|c|}
\hline الدلالة & & الحرية & المعياري & الحسابي & & & \\
\hline \multirow[t]{2}{*}{$\cdot, \cdot r$} & \multirow[t]{2}{*}{2.14} & \multirow[t]{2}{*}{ ror } & 1.49 & 7.76 & 200 & علوم طبيعية & \multirow[t]{2}{*}{ الأصالة } \\
\hline & & & 1.38 & 7.43 & 155 & علوم شرعية & \\
\hline \multirow[t]{2}{*}{$\cdot, 1}$. & \multirow[t]{2}{*}{1.65} & \multirow[t]{2}{*}{ ror } & 1.59 & 7.90 & 200 & علوم طبيعية & \multirow[t]{2}{*}{ الطلاقة } \\
\hline & & & 1.24 & 7.65 & 155 & علوم شرعية & \\
\hline \multirow[t]{2}{*}{$\cdot, \cdot r$} & \multirow[t]{2}{*}{2.31} & \multirow[t]{2}{*}{ ror } & 1.46 & 7.89 & 200 & علوم طبيعية & \multirow[t]{2}{*}{ المرونة } \\
\hline & & & 1.26 & 7.55 & 155 & علوم شر عية & \\
\hline \multirow[t]{2}{*}{$\cdot, \cdot 1$} & \multirow[t]{2}{*}{2.52} & \multirow[t]{2}{*}{ ror } & 1.42 & 8.08 & 200 & علوم طبيعية & \multirow[t]{2}{*}{ الحساسية بالمشكلات } \\
\hline & & & 1.21 & 7.72 & 155 & علوم شر عية & \\
\hline \multirow[t]{2}{*}{$\cdot, \ldots 1$} & \multirow[t]{2}{*}{3.31} & \multirow[t]{2}{*}{ ror } & 1.37617 & 7.98 & 200 & علوم طبيعية & \multirow[t]{2}{*}{ المخاطرة } \\
\hline & & & 1.27092 & 7.50 & 155 & علوم شر عية & \\
\hline \multirow[t]{2}{*}{$\cdot, \cdot r$} & \multirow[t]{2}{*}{3.17} & \multirow[t]{2}{*}{ ror } & 5.65428 & 39.60 & 200 & علوم طبيعية & \multirow[t]{2}{*}{ الدرجة الكلية } \\
\hline & & & 4.50322 & 37.84 & 155 & علوم شرعية & \\
\hline
\end{tabular}

يتضح من الجدول (7 (1) وجود فروق ذات دلالة إحصائية بين منوسطات نقدير ات المعلمين لمستوى الإبـداع لاى قادة مدارس المرحلة الثانوية بمحافظة المخواة تبعاً لمتغير (التخصص الدراسي)لصالح تخصص العلوم الطبيعيــة

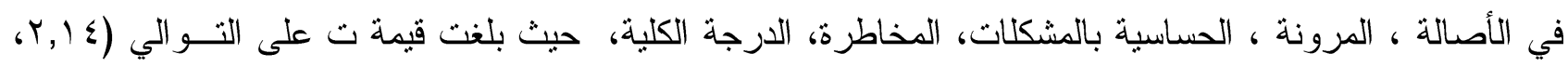

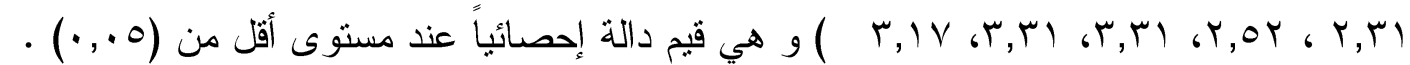

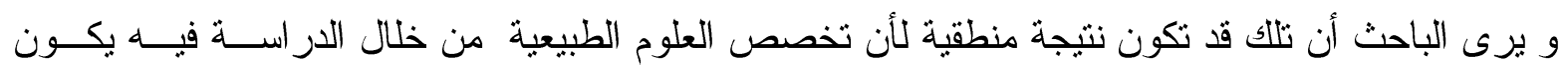
التزكيز على منهج البحث العلمي يمكن الدارس فيه من التعبير عن العلاقات بين الأثياء بيسر ويزيد مستوى تصــوره للأشياء و الأحداث النتائج المتعلقة بالسؤال الخامس و و الذي ينص على " هل توجد علاقة ارتباطية ذات دلالة إحصائية بين درجة ممارسة إدارة التغيير ومستوى الإبداع لاى قادة مدارس المرحلة الثانوية من وجهة نظر المعلمين ؟ لاختبار العلاقة بين درجة ممارسة إدارة التغيير ومستوى الإبداع لدى قادة مدارس المرحلة الثانوية من وجهـــة نظـــر (IV) المعلمين ، نم استخدام معامل ارتباط بيرسون و النتائج مبينة في جدول جدول (IV)

معاملات الارتباط لبيرسون بين درجة ممارسة إدارة التغيير ومستوى الإبداع لدى قادة مدارس المرحلة الثانوية من وجهة نظر المعلمين

\begin{tabular}{|c|c|c|c|c|c|c|}
\hline الكلية للإبداع الإدراع & المخاطرة & بالمشكاسية & المرونة & الطلاقة & الأصالة & الإدارة التغيير الإيداع الإداري \\
\hline
\end{tabular}




\begin{tabular}{|c|c|c|c|c|c|c|}
\hline$* * ., 07$ & $* *, \varepsilon$. & $* *, \mu \nu$ & $* *, \leq 1$ & $* *, 0$ & $* *, \leq 1$ & رؤية المدرسة ورسالتها \\
\hline$* *$, oV & $* *, r y$ & $* *, r_{0}$ & $* *, \leq 9$ & $* *, \leq ५$ & $* *, \leqslant V$ & الإبداع و الابتكار العلمي \\
\hline$* *, 0 \Lambda$ & $* *, r \varepsilon$ & r & $* *,, \leq 0$ & $* *, 01$ & $* *, O r$ & ثوالإدارية التغييــر التظظيمــي \\
\hline$* *, V r$ & $* *, \leqslant 9$ & $* *,, \leq 0$ & $* *, \leqslant r$ & $* *, \Sigma \Gamma$ & $* *, \varepsilon r$ & القدوة الحسنة \\
\hline$* *, V V$ & $* *, 0$ & ** & $* *, 0 \mathrm{~V}$ & $* *, 71$ & $* * .09$ & الأتغبير الكلبـة لــادارة \\
\hline
\end{tabular}

*دال عند مستوى الدلالة 0,.

".*."

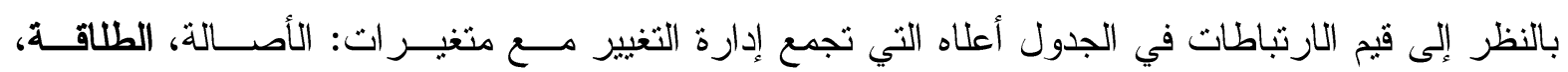
المرونة، الحساسية بالمشكلات، المخاطرة، الدرجة الكلية للإيداع الإداري لناحظ أن هنالك علاقة ارتباطيه موجبة دالة الدئ إحصائياً عند مستوى (1 •, ·) بين إدارة التغيير و أبعاد الإبداع الإداري (الأصالة ، الطلاقة ، المرونـــة ، الحساســـية

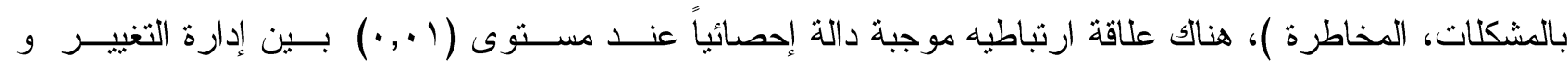
الدرجة الكلية للإبداع الإداري مما سبق نجد أن إدارة التغيير ترثبط مع الإبداع الإداري و أبعاده (الأصالة ، الطلاقة ، المرونة ، الحساسية

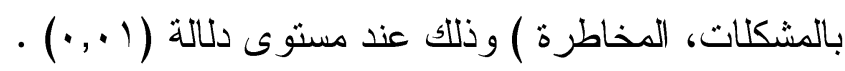

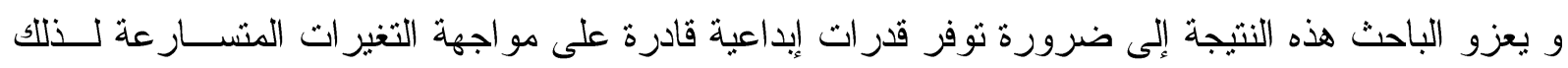
أصبح الإبداع الإداري وظيفة أساسية للتغيير في المنظمات الحديثة، كما أن الحاجة إلى الإبداع وظيفة أساسية للتغييـر

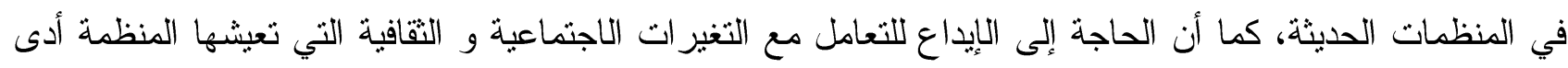
إلى حاجة الإدارة لتلك العلاقة بين الإبداع الإداري و عملية التغيير، لذلك نجد أن العلاقة ارتباطية طردية.

نتائج الدراسة توصلت الدر اسة إلى النتائج الأتية: 1 - أثبتت النتائج أن مستوى إدارة التغيير لدى مديري المدارس الثانوية جاءت مرتفعة حيث بلغ المتوسط الكلي لهــا (r,乏V)

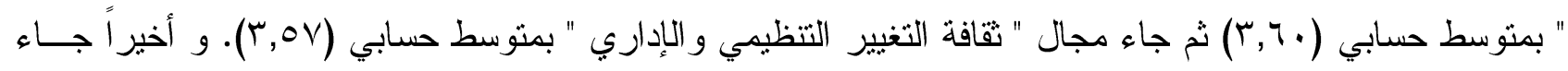
"إدارة التغيير " بمتوسط حسابي (ع (r, بابط). ץ- لا توجد فروق ذات دلالة إحصائية بين متوسطي تقدير ات المعلمين لدرجة ممارسة قادة مدارس المرحلة الثانويـــة

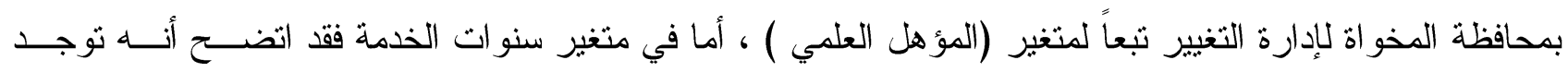

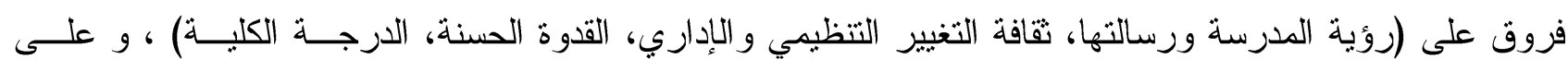
المحور الكلي. في المجال الأول "رؤية المدرسة ورسالتها" فقد كانت لصالح من عدد سنوات خدمتهم أكبر في مقابـلـل

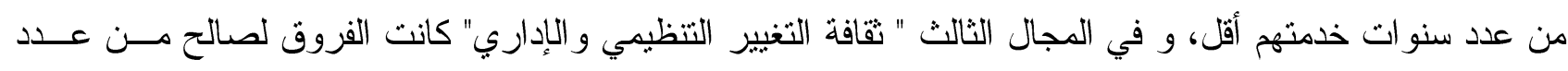

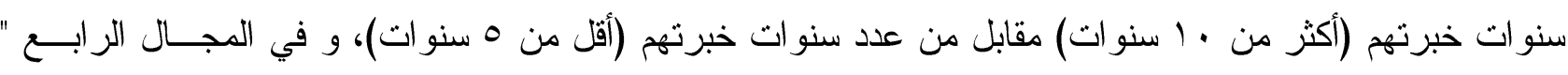
القدوة الحسنة" كانت الفروق لصالح من عدد سنوات خبرثهم (أكثر من · ا سنوات) مقابل من عدد سنوات خبـرتهم 


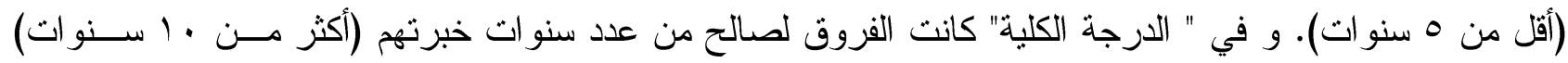

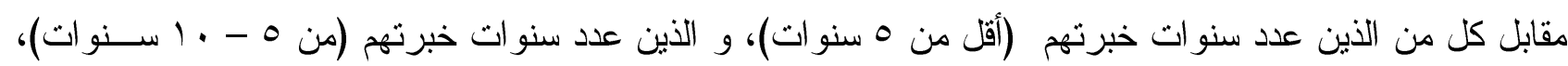
و عدم وجود فروق في مجال : الإبداع والابتكار العلمي. أما في متغير التخصص الدراسي فتبين وجود فروق ذات دلالة إحصائية بين منوسطات تقــير ات المعلمـينين

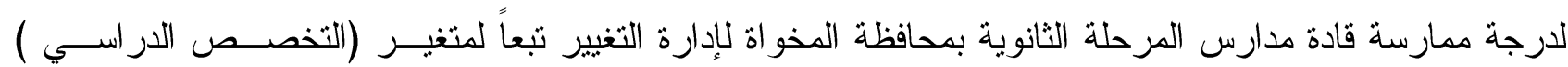
لصالح تخصص العلوم الطبيعية في القدوة الحسنة ، الدرجة الكلية.

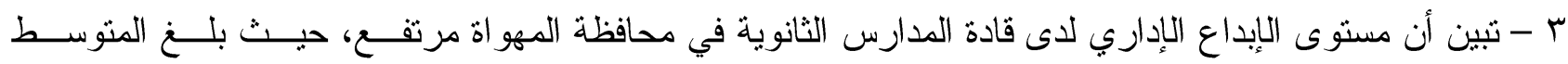

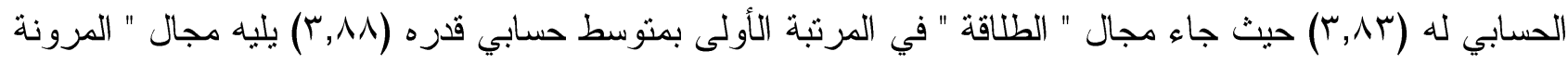

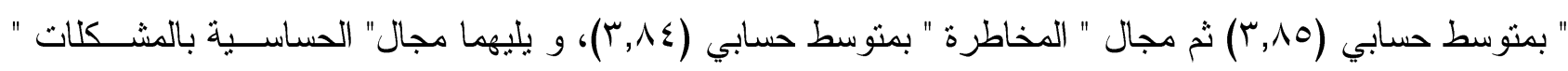

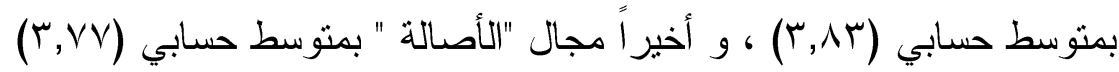

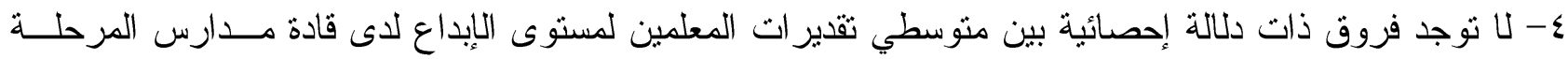

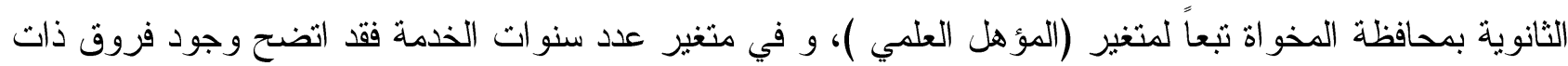

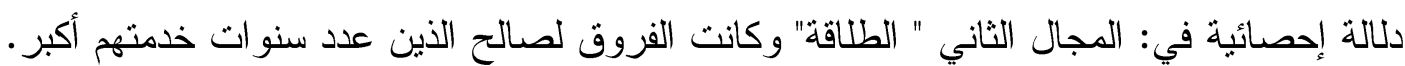

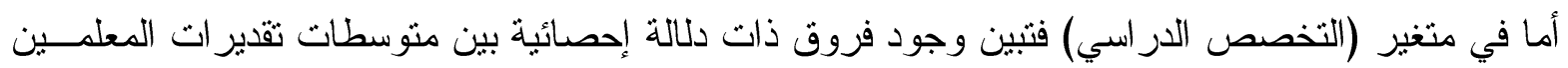

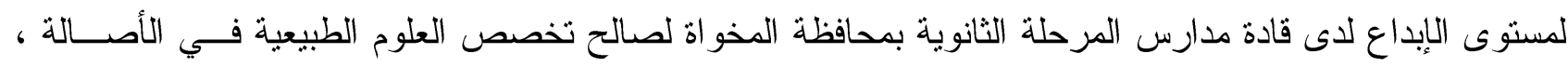
المرونة ، الحساسية بالمشكلات، المخاطرة، الدرجة الكلية.

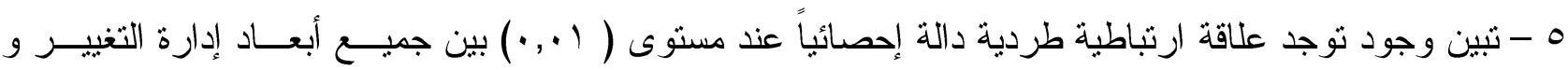

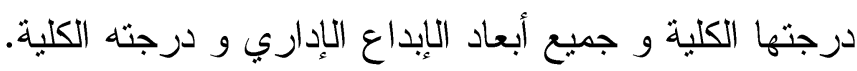

\section{توصيات الدراسة}

في ضوء نتائج الدر اسة خلصت الدر اسة إلى مجموعة من التوصيات أهميها:

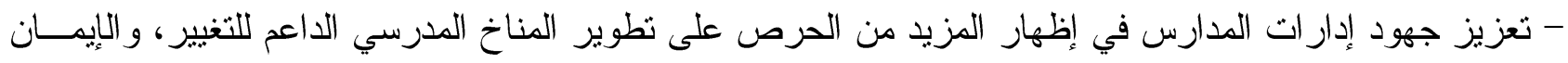

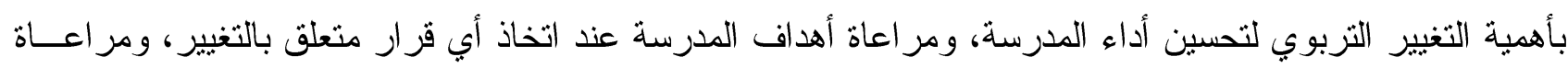

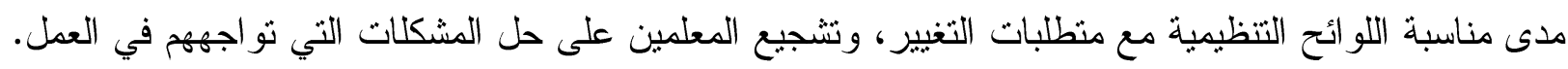

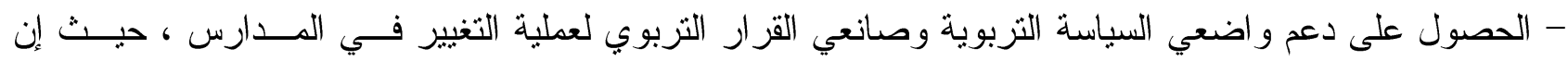
مساندتهم لجهود التغيير و التطوير يضمن للتنغيير الاستمر ارية وتحقيق نتائج أكثر فعالية. - عقد دورات تدريبية لقادة المدارس الثانوية للتنريب علي التغيير وكيفية إدارة هذا التغيير و الخطوات اللازمة لذللك.

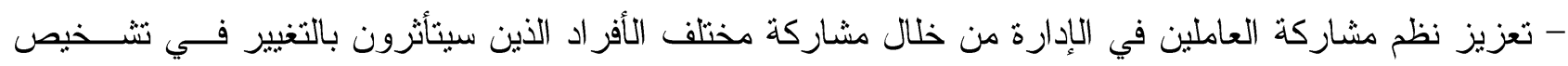

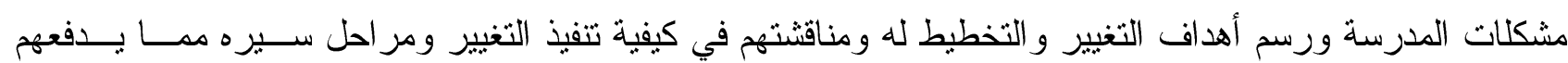
للتحمس لله و الالتز ام بتتفيذه ومثابعته. - إنثاء مر اكز متخصصة في مديريات التربية و النعليه، لكي تقوم بتوفير المعلومات اللازمة للتغيير و تكون حاضنة لإبداع الإداري في المدارس.

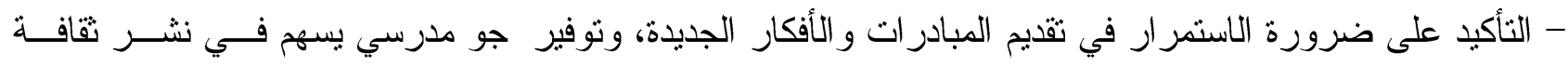

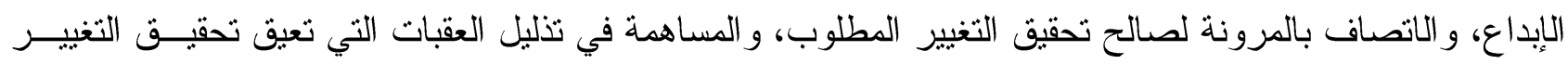


المنشود، وتحفيز المعلمين لإتقان العمل لإحداث التغيير المنشود، وتقبل الأفكار المبتكرة وتوظيـــ التكنولوجيــا فـي

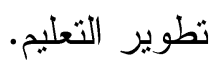

- يجب مشاركة قادة المدارس في المؤتمر ات و الندو ات وورش العمل، وذلك لنقــل رؤيــتهم الإِبداعيــة للغيــر و

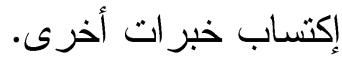

مقترحات الدراسة

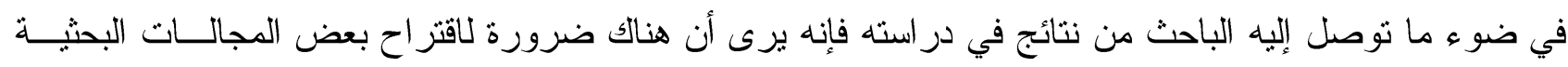
ومن أهمها:

- إجر اء در اسة حول تصميم بر امج تدريبية لتطوير أداء قادة المدارس الثانوية في مجــال الإبــاع الــإداري و إدارة التغيير - التر

- إجر اء مثل هذه الدراسة من وجهة نظر قادة المدارس أنفسهر و من وجهة نظر مشرفي الإدارات المدرسية.

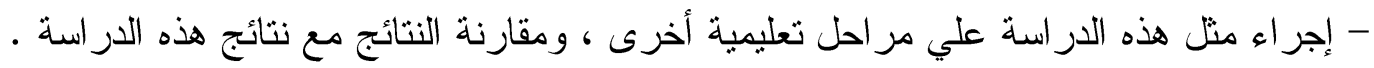

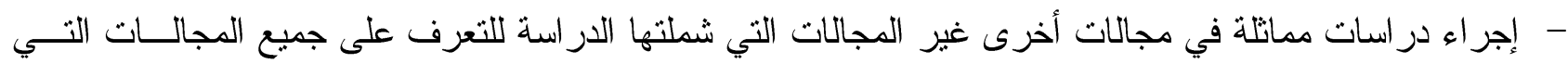

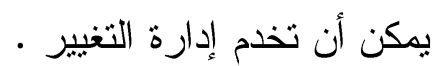
- تصور مقترح لإدارة التغيير في المدارس الثانوية. - دور إدارة التغيير في تحقيق أهداف التعليم الثانوي.

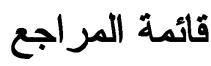

أوناً: المراجع العربية أبو سالم، دعاء أحمد خليل (V • Yم). درجة ممارسة مديري المدارس الحكومية بمحافظات غزة لإدارة التغيير وعلاقتها بضغوط العمل لليهم. رسالة ماجستير غير منشورة، الجامعة الإسلامية، غزة.

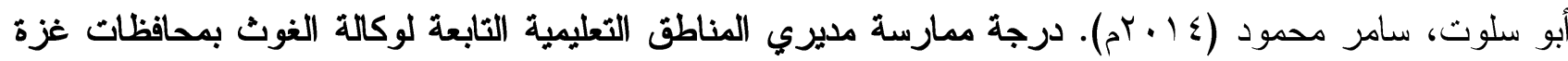
لإدارة التغيير من وجهة نظر مرؤوسيهم وعلاقتها بضغوط العمل لديهم. رسالة ماجستير غير منشورة،

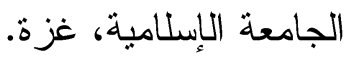
أبو العلا، ليلى (r ا ـ rم). مفاهيم ورؤى في الإدارة و القيادة التربوية بين الأصلالة والحداثة. عمان: دار يافا العلمية لالنشر و التوزيع.

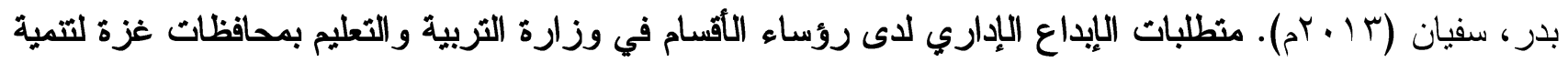

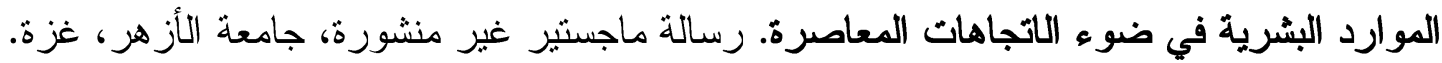

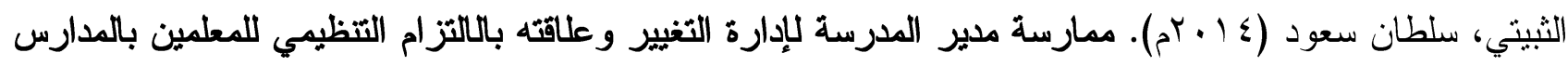

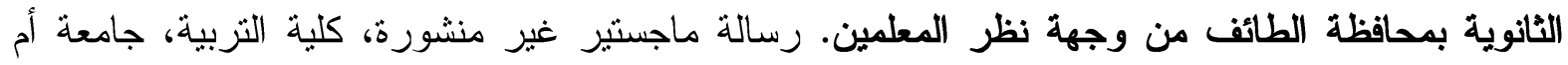
القرى، مكة المكرمة، المملكة العربية السعودية.

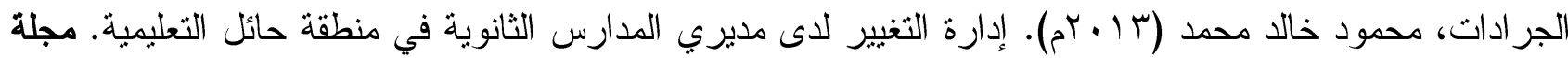

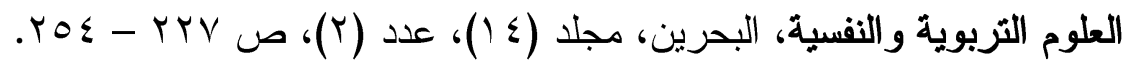


الحارثي، مشعل مبارك (r ( • rم). واقع تطبيق عناصر الإبداع الإداري وأبرز معوقاته لدى مديري المدارس الثانوية في محافظة جدة. رسالة ماجستير غير منشورة. جامعة أم القرى، مكة المكرمة. الحريري، ر افدة عمر (11 • بم). إدارة التغيير في المؤسسات التربوية. طا ـ. عمان: دار الثقافة للنشر و التوزيع. الحريزي، ر افدة عمر (V . . .rم). التخطيط الاستر اتيجي في المنظومة المدرسية. عمّان، دار الفكر . الحشاش، أحمد سعيد (ع ا • rم). تصور مقترح لتعزيز ممارسة مديري مدارس وكالة الغوث الدولية بمحافظات غزة للإبداع الإداري. رسالة ماجستير غير منشورة، الجامعة الإسلامية، غزة. الخضيري، محسن أحمد (r...rم). إدارة التغيير مدخل اقتصادي للسيكولوجية الإدارية للتعامل مع متغيرات الحاضر. دمشق: دار الرضا للمعلومات.

خطاطبة، غادة محمود († ا • rم). درجة ممارسة مديري المدارس الثانوية الحكومية في محافظة عجلون للإبداع الإداري و علاقتها بفاعلية المعلمين من وجهة نظرهم. رسالة ماجستير غير منشورة، جامعة جرش، الأردن. ربيع، محمـــ رجب، (V V • Y م). درجة ممارسة القيادة الموزعة لدى مديري مدارس وكالة الغوث في محافظات غزة وعلاقتها بالإبداع الإداري من وجهة نظر معلميهم. رسالة ماجستير غير منشورة، جامعة الأز هر ، غزة. الز املي، يوسف إسماعيل (r ا • rم). التمكين وعلاقته بالإبداع الإداري لدى مديري مدارس وكالة الغوث الدولية في محافظات غزة. رسالة ماجستير غير منشورة، الجامعة الإسلامية، غزة.

الز هر اني، ضيف الله سعيد (r ( • م). مستوى الذكاء الانفعالي وعلاقته بالإبداع لدى مديري المدارس في مدينة الطائف. رسالة ماجستير غير منشورة، كلية الثربية، جامعة الباحة، المملكة العربية السعودية. الز هر اني، سعد (9 . . بم). واقع ممارسة قيادة التغيير من قبل مديري مر اكز الإشراف التربوي بمنطقة مكة المكرمة. رسالة ماجستير غير منشورة، جامعة أم القرى، مكة المكرمة. سلام، سليم (ع . . rم). ثقافة المؤسسة والتغيير · رسالة ماجستير غير منشورة، كلية العلوم الاقتصادية وعلوم التيسير، جامعة الجز ائر ، الجزائر. السلمي، فه عوض الله (1 . . rم). ممارسة إدارة الوقت وأثرها في تتمية مهارات الإبداع الإداري لدى مديري مدارس المرحلة الثانوية بتعليم العاصمة المقدة. رسالة ماجستير غير منشورة، جامعة أح القرى، مكة المكرمة.

السويدان، طارق محمد و العدلوني، محمد أكرم (V . . rم). مباديء الإيداع. طr. الرياض: قرطبة للنشر و التوزيع. الثاعر ، حسين سالم (7 1 • بم). الإبداع الإداري وعلاقته بالمهارات القيادية لدى مديري مدارس وكالة الغوث الدولية بمحافظات غزة من وجهة نظر المعمين. رسالة ماجستير غير منشورة، جامعة الأزهر ، فلسطين. شاهين، عوني وز ايد، حنان (9 . .rم). الإبداع دراسة في الأسس النفسية والاجتماعية والتربوية لظاهرة الإيداع الإنسانية. عمان: دار الثروق للنشر و التوزيع.

الثقحاء، عادل (r . . rم). علاقة الأنماط القيادية بمستوى الإبداع الإداري (دراسة مسحية على العاملين في المديرية العامة للجوازات بالرياض). رسالة ماجستير غير منشورة، جامعة نايف للعلوم الأمنية، السعودية. شقورة، منير حسن (r ا • rم). إدارة التغيير وعلاقتها بالإيداع الإداري لدى مديري المدارس الثانوية في محافظات غزة من وجهة نظر المعلمين. رسالة ماجستير غير منشورة، جامعة الأزهر، غزة. 
العامري، عبد الله محمد علي (V . . rم). أنماط القيادة السائدة وفق نظرية الخط المستمر وعلاقتها بإدارة التغيير في المدارس الثانوية للبنين والبنات بمحافظة بيشة. رسالة ماجستير غير منشورة، جامعة أم القرى، مكة

$$
\text { المكرمة. }
$$

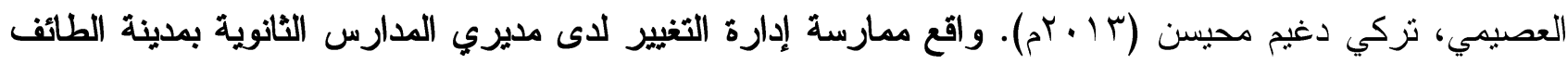

من وجهة نظر المشرفين التربويين. رسالة ماجستير غير منشورة، جامعة أم القرى، مكة المكرمة.

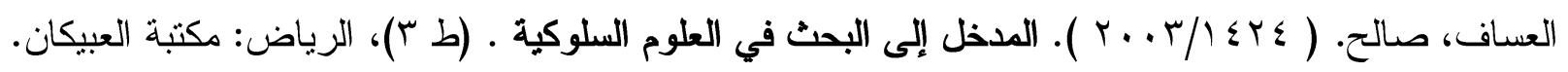

علي، أمينة عبد القادر و الحاكم، علي عبد الله (10 • rم). العلاقة بين مقومات ومعوقات الإبداع الإداري بالمؤسسات

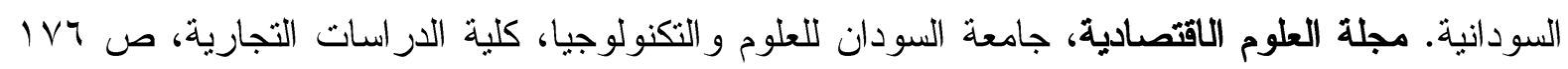

$.191-$

عماد الدين، منى مؤتمن (س + . rم). ثقويم فاعلية برنامج تطوير الإدارة المدرسية في إعداد مدير المدرسة في الأردن لقيادة التغيير • رسالة دكتور اه منشورة، مركز الكتاب الأكاديمي، عمان.

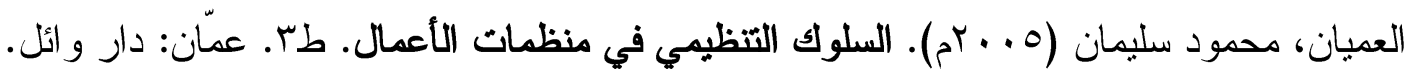

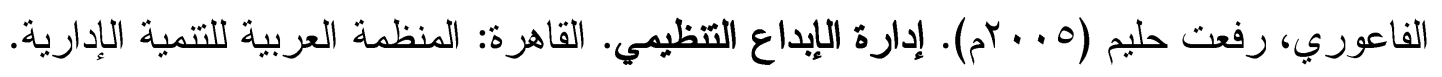
مديس، صالح سعيد أحمد (ع ا. rام). درجة ممارسة الإبداع الإداري لدى القادة التربويين في منطقة الباحة. رسالة ماجستير غير منشورة، كلية التزبية، جامعة الباحة، المملكة العربية السعودية.

المطبري، عبدالله سعود (؟ ( • rم). واقع إدارة التغيير لدى مديري المدارس الثانوية بمحافظة حفر الباطن وعلاقتها بالالتز ام التظظيمي المعلمين. رسالة ماجستير غير منشورة، جامعة أم القرى، مكة المكرمة.

نصر ، عزة جلال مصطفى (ی . . rم). الإبداع الإداري والتجديد الذاتي للمدرسة الثانوية العامة رؤية استراتيجية. الإسكندرية: المكتب الجامعي الحديث.

الهبيل، أحمد عيسى (1 . . rم). واقع إدارة التغيير لدى مديري المدارس الثانوية بمحافظات غزة من وجهة نظر

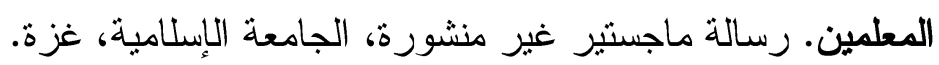

الهذلي، رجوه سمران (· ( •rم). إدارة الذات وعلاقتها بالإبداع الإداري لدى مديرات ومساعدات ومعلمات مدارس

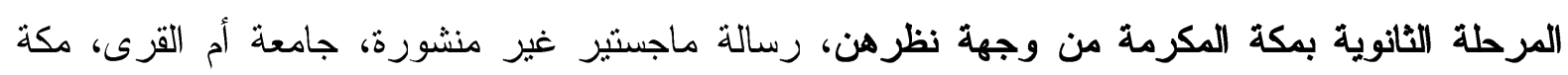

\section{المكر مة. \\ ثانياً: المر اجع الأجنبية}

Diliello, Trudy C. and Houghton, Jeffery D. (2001): "Maximizing organizational leadership capacity for the future: toward a model of self-leadership, innovation and creativity", Journal of Managerial Psychology, Vol. 21. No. 4.

Englehardt, Charles \& Simmons, Peter (2002): Creating and organizational space for learning. The Learning Organization, Vol. 9, No. 1: 9- 30.

Harrison, Charles (2010). The Self- Aware Organization: A Metacognitive Approach to Change Management in a Small Rural School. Doctoral Dissertations, ProQuest LLC, Ed.D. Dissertation, University of Phoenix, ED521577, ERIC.

Razzaq, J. (2012). The management of educational chang in Pakistani educational institutions. University of Glasgow, Unpublished doctoral thesis. 
Redish, Traci \& Others, (2006). "Design and implementation of: a web based portfolio for aspiring educational leaders: a comprehensive, evidence - based model", J. Educational Technology Systems, Vol. 34, No. 3.

Ismail, Maryam (2005): "Creative Climate and Learning Organization factors: their contribution towards Innovation", Leadership \$ Organization Development Journal, Vol. 26, No. 8.

Moye, Melinda J. et. al, (2005); Teacher - principal relationships: Exploring linkages between empowerment and interpersonal trust". Journal of Educational Administration, Vol. 43. No. 3 